\title{
Two new and two known species of the genus Paraoxydirus Jairajpuri and Ahmad, 1978 (Nematoda: Dorylaimida) from Western Ghats of India
}

\author{
S. KUMAR, W. AHMAD* \\ Nematode Biodiversity Research Laboratory, Department of Zoology, Aligarh Muslim University, Aligarh - 202002 INDIA, \\ *E-mail: ahmadwasim57@gmail.com
}

Article info

Received October 13, 2020

Accepted February 15, 2021

\section{Summary}

Two new and two known species of the genus Paraoxydirus Jairajpuri and Ahmad, 1978 are described and illustrated from Western Ghats of India. P. vulvalpapillatus $n$. sp. is characterized by having large sized body $(L=4.6-4.8 \mathrm{~mm})$; lip region continuous with completely amalgamated lips; amphidial fovea cup - shaped; $5-6 \mu \mathrm{m}$ long odontostyle; 11 - $13 \mu \mathrm{m}$ long odontophore; pharyngeal expansion about $28-36 \%$ of neck length; transverse vulva; vulval papillae conspicuous; males with $46-54 \mu \mathrm{m}$ long spicules; $11-14$ continuous ventromedian supplements and long filiform tail similar in both sexes. $P$. indicus $n$. $\mathrm{sp}$. is characterized by having large sized body $(\mathrm{L}=4.0-4.8 \mathrm{~mm})$; lip region poorly offset with amalgamated lips; amphidial fovea cup-shaped; $7-8 \mu \mathrm{m}$ long, robust odontostyle; 17 - $18 \mu \mathrm{m}$ long odontophore; pharyngeal expansion about $32-40 \%$ of neck length; 21 - $26 \mu \mathrm{m}$ long cardia; longitudinal vulva; 748 - $894 \mu \mathrm{m}$ long filiform tail; males with $45-54 \mu \mathrm{m}$ long spicules and $12-15$ continuous ventromedian supplements. $P$. gigas Jairajpuri, 1964 and $P$. novus Jairajpuri, 1965 are redescribed based on specimens collected from several localities. A diagnostic Key and compendium to the identification of its eight valid species is provided.

Keywords: Compendium; description; India; new species; Paraoxydirus; Western Ghats

\section{Introduction}

Jairajpuri and Ahmad (1978) proposed a new genus Paraoxydirus for Oxydirus species having asymmetrical lip region and odontostyle and short fusiform basal expanded part of the pharynx enclosed in a thick sheath of sinistrally spiral muscles, and designated $P$. magnus (= Oxydirus magnus Timm, 1964) as its type species and also transferred $P$. gigas $(=0$. gigas Jairajpuri, 1964), and $P$. novus ( $=0$. novus Jairajpuri, 1965) from Oxydirus Thorne, 1939 to this genus. Ferris, Goseco and Ferris (1980) revised the genus Oxydirus and proposed a new genus Tarjanius with two new species Tarjanius pelinus Goseco, Ferris \& Ferris, 1980 and T. cavenessi Goseco, Ferris and Ferris, 1980 and also transferred three species, viz., 0 . magnus, 0 . gigas and 0 . novus from Oxydirus to this genus and provided a key for the identification of five valid species. Later, Ferris, Goseco and Ferris (1981) synonymised Tarjanius with Paraoxydirus. Dhanam and Jairajpuri (1998) added a new species $P$. abnormus from India. No further species has been added to this group since then. In recent years, we collected several populations of this rare genus from Western Ghats, a biodiversity hot spot in India. Some specimens were also collected from North-east India, another biodiversity hot spot in India. On detailed study these populations were found to represent four species, two of which are new to science. All the four species are described in the following. A diagnostic compendium as well as key to species of the genus is also provided.

\footnotetext{
* - corresponding author
} 


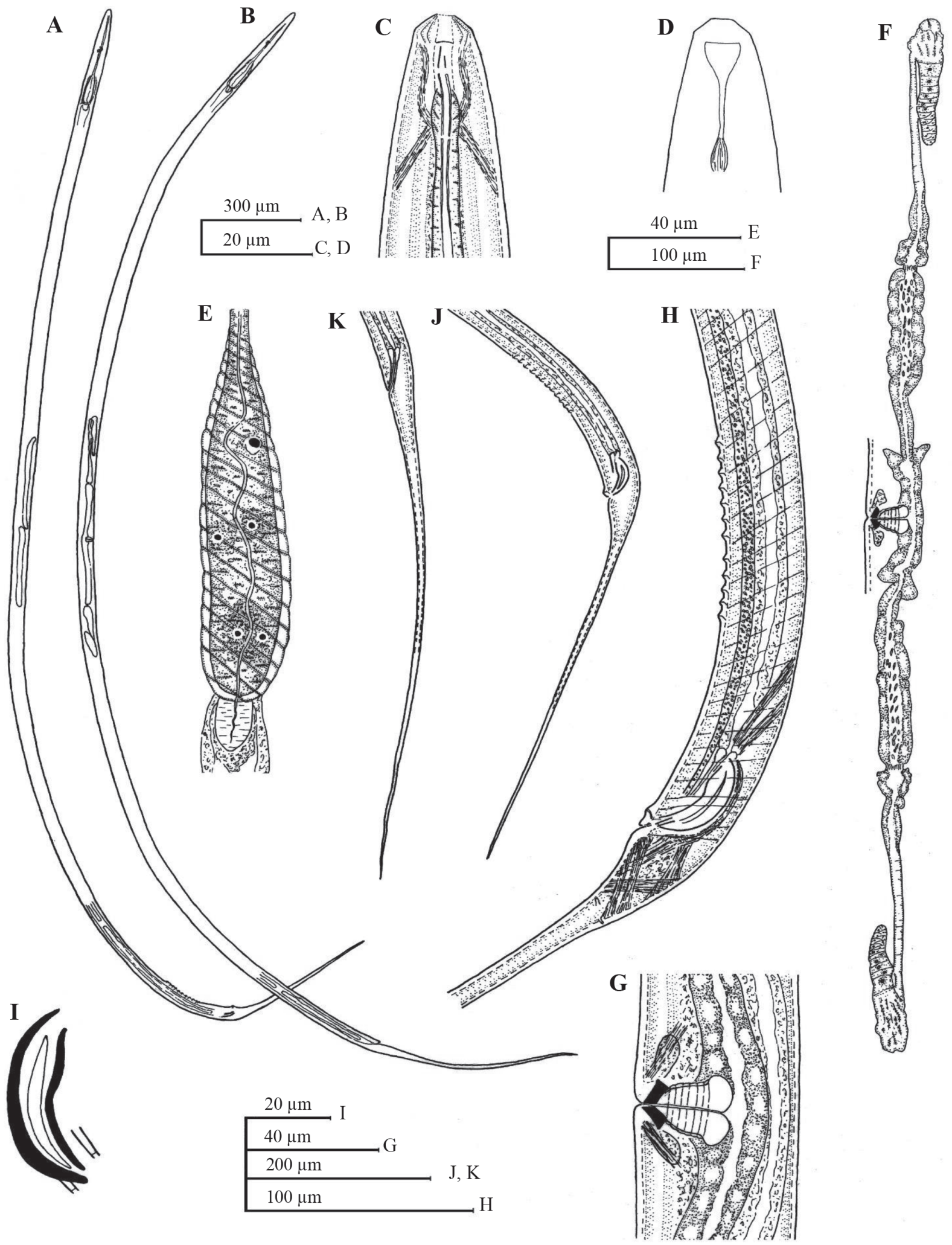

Fig. 1. Paraoxydirus gigas Jairajpuri, 1964. (A) Entire male; (B) entire female; (C) anterior region; (D) anterior end showing amphid; (E) expanded part of pharynx; (F) female genital system; (G) vulval region; (H) male posterior region; (I) spicule; (J) male posterior region; (K) female posterior region. 


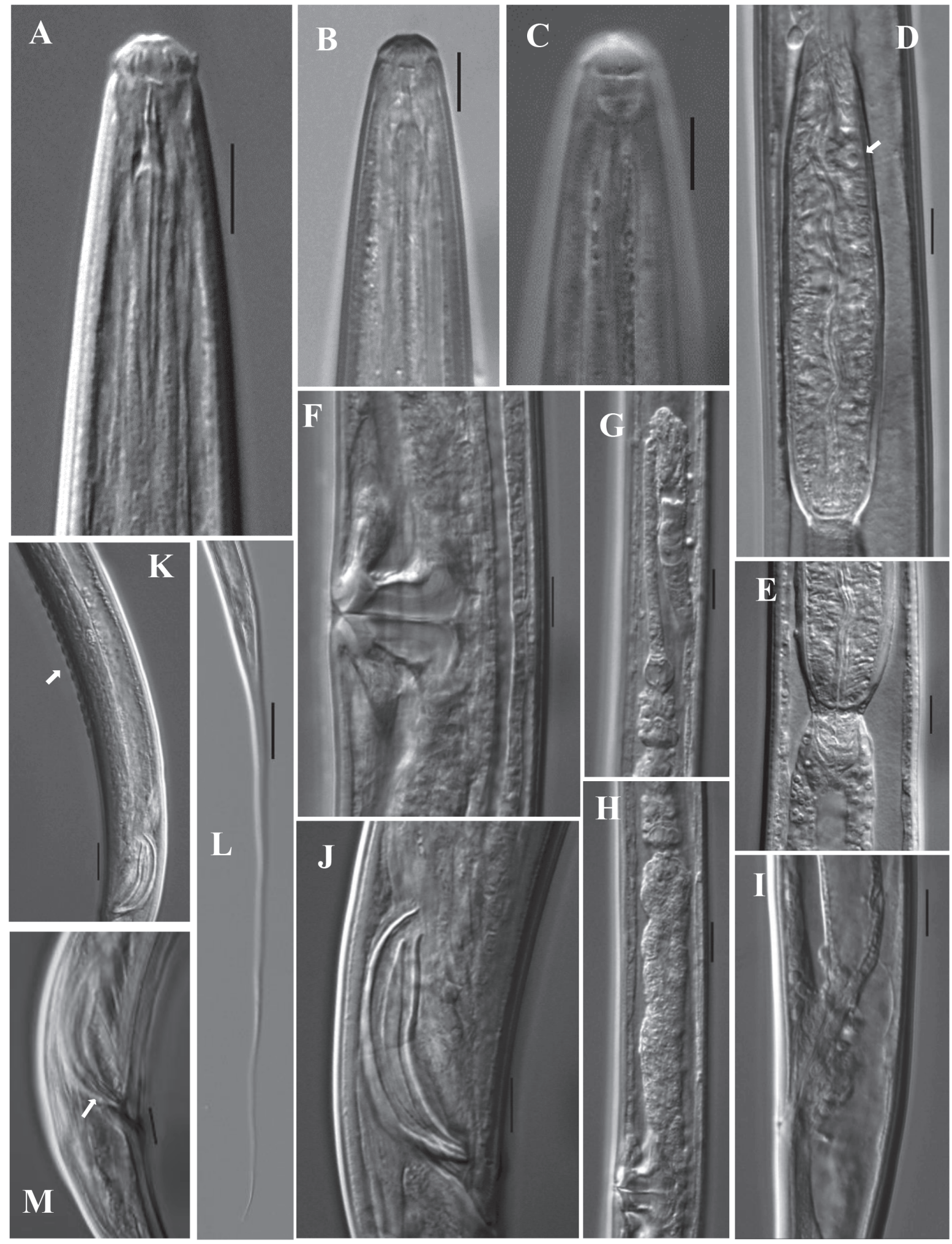

Fig. 2. Paraoxydirus gigas Jairajpuri, 1964. (A, B) Anterior region; (C) anterior region showing amphid; (D) expanded part of pharynx \& DN; (E) cardia; (F) vulval region; $(G, H)$ female genital branch; (I) rectum; (J) spicule; (K) ventromedian supplements; (L) female tail; (M) lateral guiding piece. (Scale bars: $A-F, I, J, M=10 \mu m$; $\mathrm{G}, \mathrm{H}, \mathrm{K}=20 \mu \mathrm{m} ; \mathrm{L}=100 \mu \mathrm{m})$. 


\section{Materials and Methods}

Soil samples were collected from around the roots of grasses, bushes, crop plants and forest trees in different localities of the Western Ghats (Indian states of Goa, Karnataka, Tamil Nadu and Kerala) as well as from Assam, India. Nematodes were extracted from the soil samples by Cobb's (1918) sieving and decantation and modified Baermann funnel technique. Nematode were killed and fixed in hot $4 \%$ TAF (Courtney et al., 1955) and dehydrated by slow evaporation in the desiccators containing desiccant and mounted in anhydrous glycerin on slides (Seinhorst, 1959). For scanning electron microscopy (SEM), dehydrated specimens were rehydrated then fixed in glutaraldehyde by using phosphate buffer, and dehydrated in ethanol series. Critical point dried specimens were coated with gold and observed in a JEOL JSM-65 10LV scanning electron microscope. Measurements were taken by using ocular micrometer and line illustrations were made using a drawing tube attached to OLYMPUS BX 51 Microscope. Photographs were taken with digital camera attached to "Nikon Eclipse 80i" Microscope. Photographs of the specimens were prepared by using Adobe Photoshop 7.0. Computer software. Spicule morphometrics were taken as per Peña-Santiago et al. (2014). Andrássy's (1998) as well as Loof and Coomans (1970) formula was followed for the measurements of the position of pharyngeal glands and their nuclei.

\section{Results}

\section{Paraoxydirus gigas (Jairajpuri, 1964) Jairajpuri and Ahmad, 1978}

= Oxydirus gigas Jairajpuri, 1964

= Tarjanius gigas (Jairajpuri, 1964) Ferris, Goseco and Ferris, 1980

(Figs. $1 \& 2$ )

\section{Measurements: See Table 1}

Description: Adult: Large size nematodes, slightly curved ventrad, cylindroid, tapering towards both extremities but more so towards posterior end as tail is long filiform. Cuticle with fine transverse striations, about $1.0 \mu \mathrm{m}$ thick at anterior region, similar in both sexes, $1-3 \mu \mathrm{m}$ at mid-body, $3-6 \mu \mathrm{m}$ on tail in females, and about $2 \mu \mathrm{m}$ at mid body, $2-3 \mu \mathrm{m}$ on tail in males. Lateral chords with indistinct glandular bodies, $10-16 \mu \mathrm{m}$ wide, and occupying about one-fifth to one-fourth $(19-25 \%)$ of mid-body diameter. Body pores indistinct. Lip region continuous, gradually narrowing, about 2.0 - 2.7 times as wide as high or about one-fifth to onefourth $(20-25 \%)$ of body diameter at neck base. Lips weakly angular, amalgamated, cephalic framework with poorly developed refractive elements; cephalic papillae distinct. Stoma wall poorly sclerotized. Amphidial fovea cup-shaped, their aperture occupying about $0.5-0.7$ times the lip region diameter, fusus slightly posterior to odontophore base level. Guiding ring simple, poorly developed, at $0.4-0.6$ times lip region diameter from anterior end.
Odontostyle slender, its ventral arm slightly bent at tip, 5 - 6 times as long as wide, about $0.4-0.6$ times as long as lip region diameter, its aperture about one-third of its length. Odontophore simple, rod-like, weakly developed, 1.8 - 2.8 times the odontostyle length. Nerve ring encircling the anterior slender part of pharynx at about $41-49 \%$ of neck length from anterior end. Anterior slender part of pharynx quite muscular, expanding gradually; expanded part 3.0 - 4.2 times as long as wide, $1.9-2.6$ times as long as body diameter at neck base, occupying about 28 - $35 \%$ of total neck length, enclosed in a thick sheath of sinistrally spiral muscles. Pharyngeal gland nuclei and their orifices are located as follows: $\mathrm{DO}=73-$ 75; DN = 74 - 76; DO-DN = 1.5-1.8; S1N1 = 82 - 83; S1N2 = 84; S2N = 94 as per Loof and Coomans (1970); D = $75-76$; AS1 = $30-32 ;$ AS2 = 34; K = 88 - 92; PSN = 78 as per Andrássy (1998). Cardia oblong, $1.1-2.3$ times as long as wide, occupying about one-fourth to less than one-half $(26-45 \%)$ of the corresponding body diameter.

Female: Genital system amphidelphic, both branches almost equally developed, anterior $6.7-9.3 \%(n=8)$ and posterior 7.4 $-9.6 \%(n=8)$ of total body length. Ovaries reflexed, not reaching oviduct-uterus junction, anterior $70-203 \mu \mathrm{m}$, and posterior $69-$ $250 \mu \mathrm{m}$ long, with squamous shaped oocytes arranged in single row except near tip. Oviducts joining ovary subterminally, anterior $133-240 \mu \mathrm{m}$ and posterior 147 - $240 \mu \mathrm{m}$ long, consisting of a long slender part with prismatic cells and a slightly wider pars dilatata with wide lumen. Sphincter present at oviduct-uterus junction. Uterus simple tube, but occasionally appearing bipartite $(n=1)$, differentiated into a short proximal region with distinct lumen, and a large distal part with comparatively wide lumen; anterior branch $136-295 \mu \mathrm{m}$ or $2.5-4.8$ times, and posterior $161-326 \mu \mathrm{m}$ or 3.0 - 5.3 times the corresponding body diameter long. Vagina extending inwards, about one-half to three-fifths (49-60\%) of corresponding body diameter; pars proximalis vaginae longer than wide, $18-22 \times 6-8 \mu \mathrm{m}$, with somewhat sigmoid walls, surrounded by circular muscles; pars refringens vaginae with two adjacent trapezoid-shaped pieces, $3-5 \times 7-9 \mu \mathrm{m}$, their combined width 15 - $24 \mu \mathrm{m}$; pars distalis vaginae $4-6 \mu \mathrm{m}$ with rounded walls. Vulva transverse. Prerectum $7.4-10.3$ and rectum $1.0-1.3$ times anal body diameter long. Tail long filiform, $18-21(n=8)$ times anal body diameter long. Caudal pores two; sub-dorsal and sub-ventral in position.

Male: Similar to female in general morphology, except for posterior region of the body being more ventrally curved. Genital system diorchic, with oppositely outstretched testes. In addition to the adcloacal pair, located at $10-11 \mu \mathrm{m}$ from cloacal aperture, a series 11 - 14 irregularly spaced ventromedian supplements, 7 - $19 \mu \mathrm{m}$ apart, beginning at $94-103 \mu \mathrm{m}$ from the adcloacal pair. Copulatory muscles conspicuous, beginning from level of middle of spicule to beyond the range of supplements series. Spicules typically dorylaimoid, robust slightly curved ventrad, total length along the arc 1.0 - 1.1 times as long as chord, 4.3 - 5.2 times the maximum width and $1.5-1.8$ times the body diameter at cloacal aperture. 


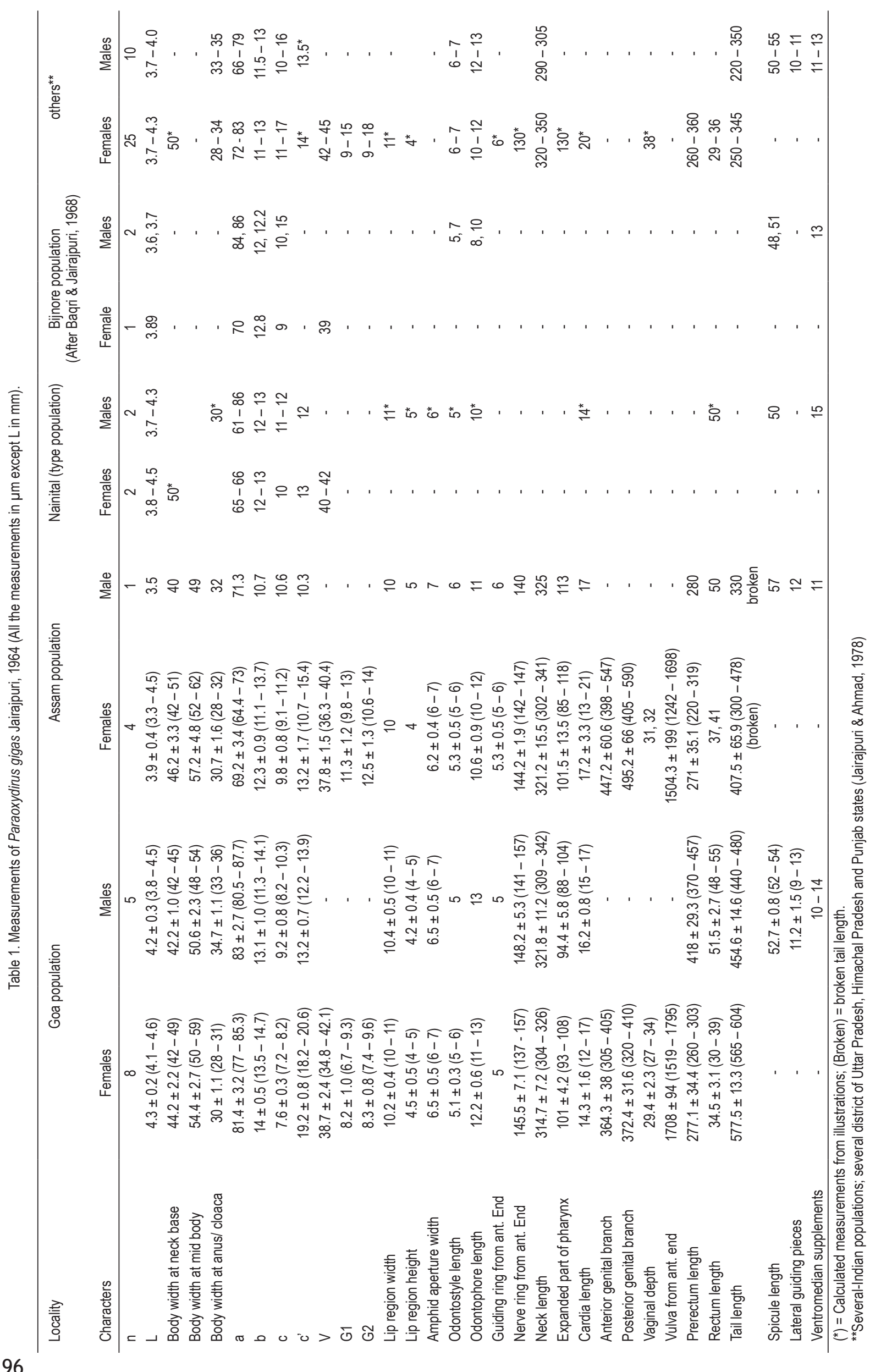



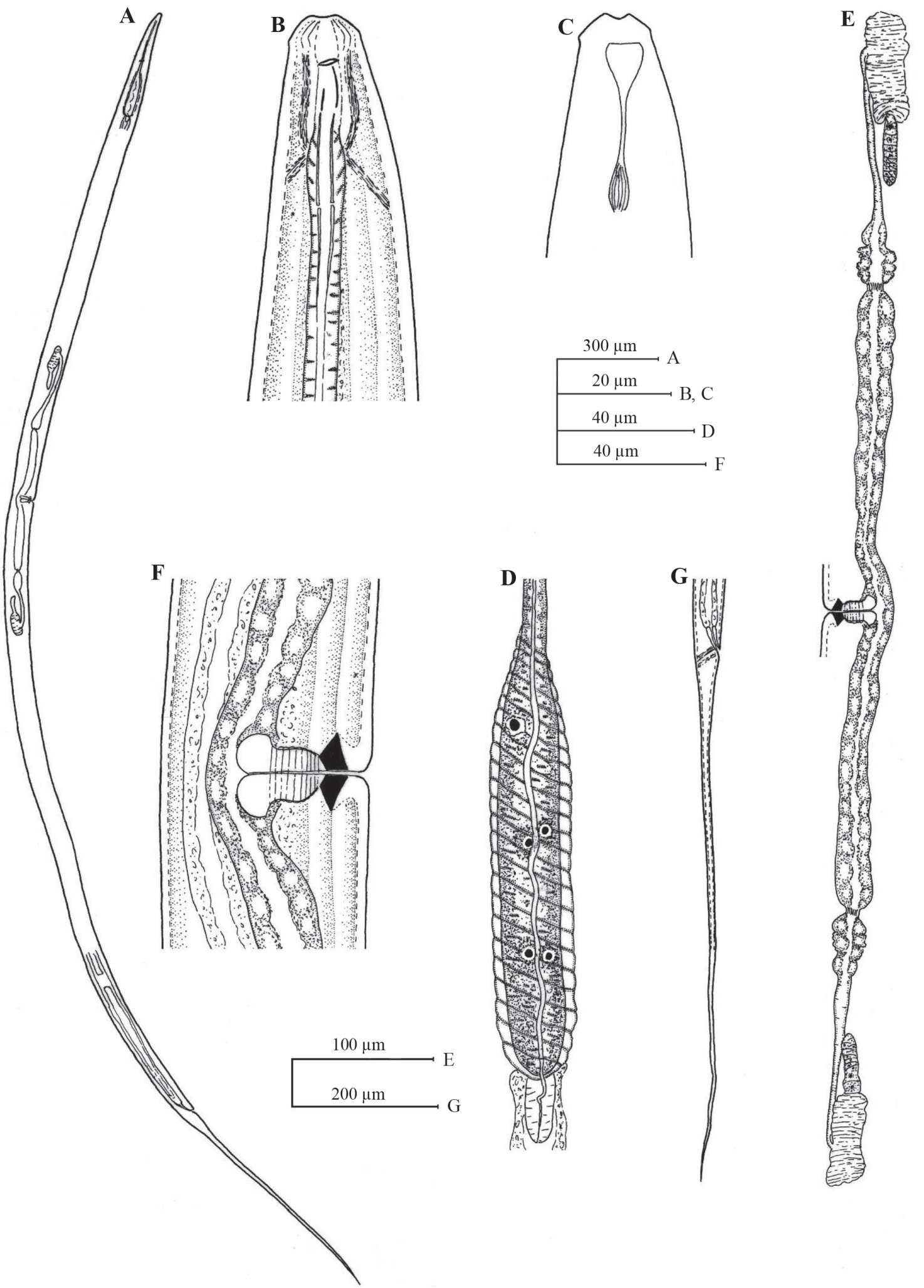

Fig. 3. Paraoxydirus novus Jairajpuri, 1965. (A) Entire female; (B) anterior region; (C) anterior region showing amphid; (D) expanded part of pharynx; (E) female genital system; (F) vulval region; $(\mathrm{G})$ female posterior region. 

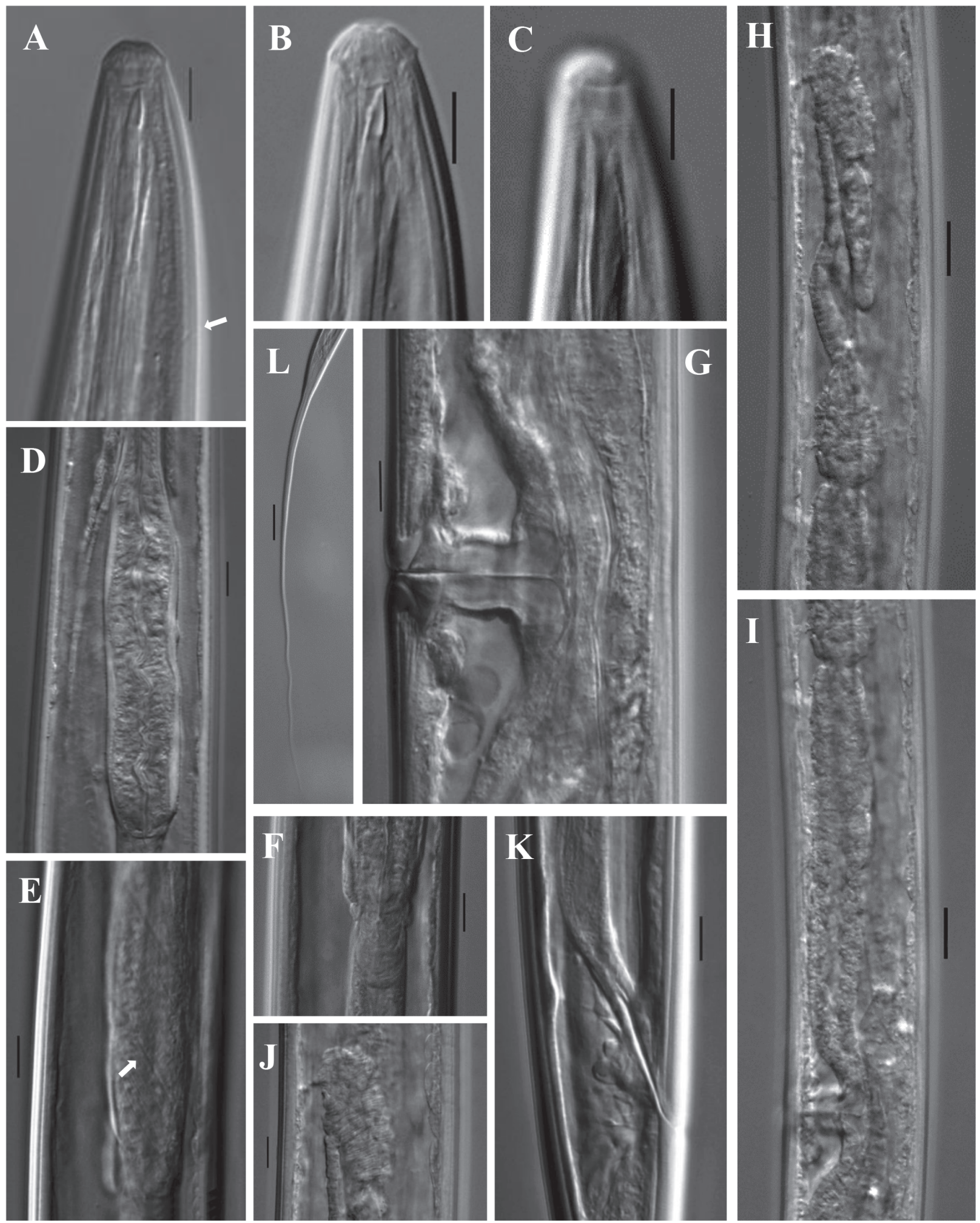

Fig. 4. Paraoxydirus novus Jairajpuri, 1965 (A) Anterior region showing body pores; (B) anterior region; (C) anterior region showing amphid; (D) expanded part of pharynx; (E) spiral muscular sheath; (F) cardia; (G) vulval region; (H, I) female genital branch; (J) proximal part of ovary showing muscular sheath; (K) rectum; (L) tail. (Scale bars: $A-G, K=10 \mu \mathrm{m} ; \mathrm{H}-\mathrm{J}=20 \mu \mathrm{m} ; \mathrm{L}=100 \mu \mathrm{m}$ ). 
Curvature about $133^{\circ}$. Dorsal contour regularly convex, ventral contour bearing prominent hump, located at $31-37 \%$ of spicules total length from its anterior end; head $5-7 \mu \mathrm{m}$ long, occupying about $9-13 \%$ of total length; median piece $16-25$ times as long as wide, occupying about $17-25 \%$ of spicules maximum width. Posterior end 3-5 $\mu \mathrm{m}$ wide. Lateral guiding pieces simple, 6 - 7 times as long as wide or about one-sixth to one-fourth of spicules length. Prerectum $8.7-13.8$ and rectum $1.4-1.6$ times cloacal body diameter long. Tail long filiform, about $12.3-13.9(n=5)$ times cloacal body diameter long. Caudal pores three; a ventral, dorsal and sub-dorsal respectively.

Habitats and localities: Soil samples collected from around the root of: i) unidentified grass from Canacona, South Goa, India; coordinates $14^{\circ} 59^{\prime} 35.21^{\prime \prime} \mathrm{N} 74^{\circ} 2^{\prime} 51.5^{\prime \prime} \mathrm{E}$ on April 18, 2016; ii) paddy from Tinsukia district, Assam, India; coordinates $27^{\circ} 30^{\prime} 0.0^{\prime \prime} \mathrm{N}$ 95'22'1.2" E on November 26, 2005.

Diagnosis and Remarks: P.gigas is characterized by having 3.3 $4.6 \mathrm{~mm}$ long body; lip region continuous, $10-11 \mu \mathrm{m}$ wide; amphidial fovea cup-shape; guiding ring weak; odontostyle slender, $5-7$ $\mu \mathrm{m}$ long; expanded part of pharynx about $28-35 \%$ of total neck length; female genital system amphidelphic; vulva transverse, pre equatorial; pars refringens vaginae present; tail long filiform similar in sexes; males with $52-54 \mu \mathrm{m}$ long spicules, $9-13 \mu \mathrm{m}$ long lateral guiding pieces and $10-14$ continuous ventromedian supplements. Jairajpuri (1964) described this species as Oxydirus gigas based on two females, two males and large number of juveniles from around roots of Psidium gujava L. from Nainital district of Uttarakhand, India. Siddiqi (1966) redescribed it based on a single male specimen from Madhya Pradesh and considered it a synonym of O. magnus Timm, 1964. Baqri and Jairajpuri (1968) reported this species from Bijnore, Uttar Pradesh and concluded that both these species are distinctly different. Jairajpuri and Ahmad (1978) recorded this species from several localities (Lakhimpur Kheri, Uttar Pradesh; Mandi, Kulu, Manali, Himachal Pradesh and Pathankot, Punjab) of India and transferred it to their newly proposed genus Paraoxydirus. Ferris, Goseco and Ferris (1980) in their revision of Belondiroidea provided description of this species based on the study of type material and placed it under their new genus Tarjanius as T. gigas. Ferris, Goseco and Ferris (1981) latter synonymized Tarjanius with Paraoxydirus. The present population of $P$. gigas from Goa and Assam India, conforms well with the original description except in having comparatively slender body ( $a=77-85$ vs $65-66)$; presence of vaginal sclerotization ( $v s$ vaginal sclerotization not mentioned); longer tail $(c=7.2-8.2$ vs $10 ; c^{\prime}=18-20.6$ vs 13 ); slightly longer spicules ( $52-57$ vs 50 $\mu \mathrm{m})$; it differs from the Madhya Pradesh male specimen in having longer tail ( $c=8.2-10.3$ vs 14$)$; longer spicules $(52-57$ vs 49 $\mu \mathrm{m})$ and slightly longer lateral guiding pieces (11 - 13 vs $10 \mu \mathrm{m})$; from Bijnore population it differs, in having slightly longer body $(\mathrm{L}=$ $4.0-4.36$ vs $3.9 \mathrm{~mm}$ ); shorter pharynx ( $b=13.4-14.7$ vs 12.8$)$; longer tail $(c=7.2-8.2$ vs 9$)$; slightly longer spicules (52 -57 vs $48-51 \mu \mathrm{m})$, and from Uttar Pradesh, Himachal Pradesh and
Punjab populations (Jairajpuri \& Ahmad, 1978), in having longer tail ( $c=7.2-8.2$ vs $11-17 c^{\prime}=18.2-20.6$ vs 14 ). It seems, the present populations consistently have longer tail than earlier described ones. It would not be out of place to mention that in such species with very long filiform tail, the tail is generally broken, however, for comparison we have taken the measurements of only those females which have intact tail.

\section{Paraoxydirus novus (Jairajpuri, 1965) Jairajpuri and Ahmad, 1978 \\ = Oxydirus novus Jairajpuri, 1965 \\ =Tarjanius novus (Jairajpuri, 1965) Ferris, Goseco and Ferris, 1980}

(Figs. $3 \& 4$ )

Measurements: See Table 2

Description: Female: Large sized nematodes, slightly curved ventrad, cylindroid, tapering towards both extremities but more so towards the posterior end as tail is long filiform. Cuticle with fine transverse striations, about $2-3 \mu \mathrm{m}$ thick at anterior and mid-body, $4-5 \mu \mathrm{m}$ on tail. Lateral chords with indistinct glandular bodies, $9-16 \mu \mathrm{m}$ wide, and occupying about one-sixth to onefourth (14.5 - $25.6 \%)$ of mid body diameter. Ventral body pores poorly distinct, 11 in number; 6 in the pharyngeal region, 2 between pharyngeal base and vulva, and 3 from vulva to anus. Lip regions asymmetrical, slightly offset, about 2 - 3 times as wide as high or about one-fifth to one-fourth (20 - $25 \%)$ of body diameter at neck base. Lips amalgamated, cephalic framework with poorly developed refractive elements; cephalic papillae distinct. Amphidial fovea stirrup-shaped, their aperture about half of lip region diameter, fusus at level of odontophore base. Guiding ring single, very conspicuous, at $0.5-0.9$ times the lip region diameter from anterior end. Odontostyle robust, $3.2-4.0$ times as long as wide, $0.5-0.7$ times as long as lip region diameter, its aperture about one-half of its length. Odontophore simple, rod-like, 1.7 - 2.6 times the odontostyle length. Nerve ring encircling anterior slender part of pharynx at about $37-49 \%$ of the neck length from anterior end. Anterior slender part of pharynx quite muscular, expanding gradually; expanded part 3.6 - 5.2 times as long as wide, 1.7 - 2.7 times as long as body diameter at neck base, occupying about $28-41 \%$ of total neck length, enclosed in a thick sheath of sinistrally spiral muscles. Pharyngeal gland nuclei and their orifices are located as follows: $\mathrm{DO}=67-71$; DN $=67-72$; DO-DN $=0.6$ 1.0; S1N1 = 75; S1N2 = 80; S2N $=93$ as per Loof and Coomans (1970); $\mathrm{D}=67-71 ;$ AS1 $=20 ;$ AS2 $=34 ; \mathrm{K}=58 ; \mathrm{PSN}=78$ as per Andrássy (1998). Cardia oblong, $1.0-1.8$ times as long as wide, occupying about one-third of the corresponding body diameter. Genital system didelphic-amphidelphic, both the sexual branches almost equally developed, anterior $8.8-11.5 \%(n=9)$ and posterior $9-12 \%(n=9)$ of body length. Ovaries reflexed, not reaching oviduct-uterus junction, anterior $78-135 \mu \mathrm{m}$, and posterior $88-$ $145 \mu \mathrm{m}$ long, with squamous shaped oocytes arranged in single row except near tip. Oviducts joining ovary subterminally, anterior 


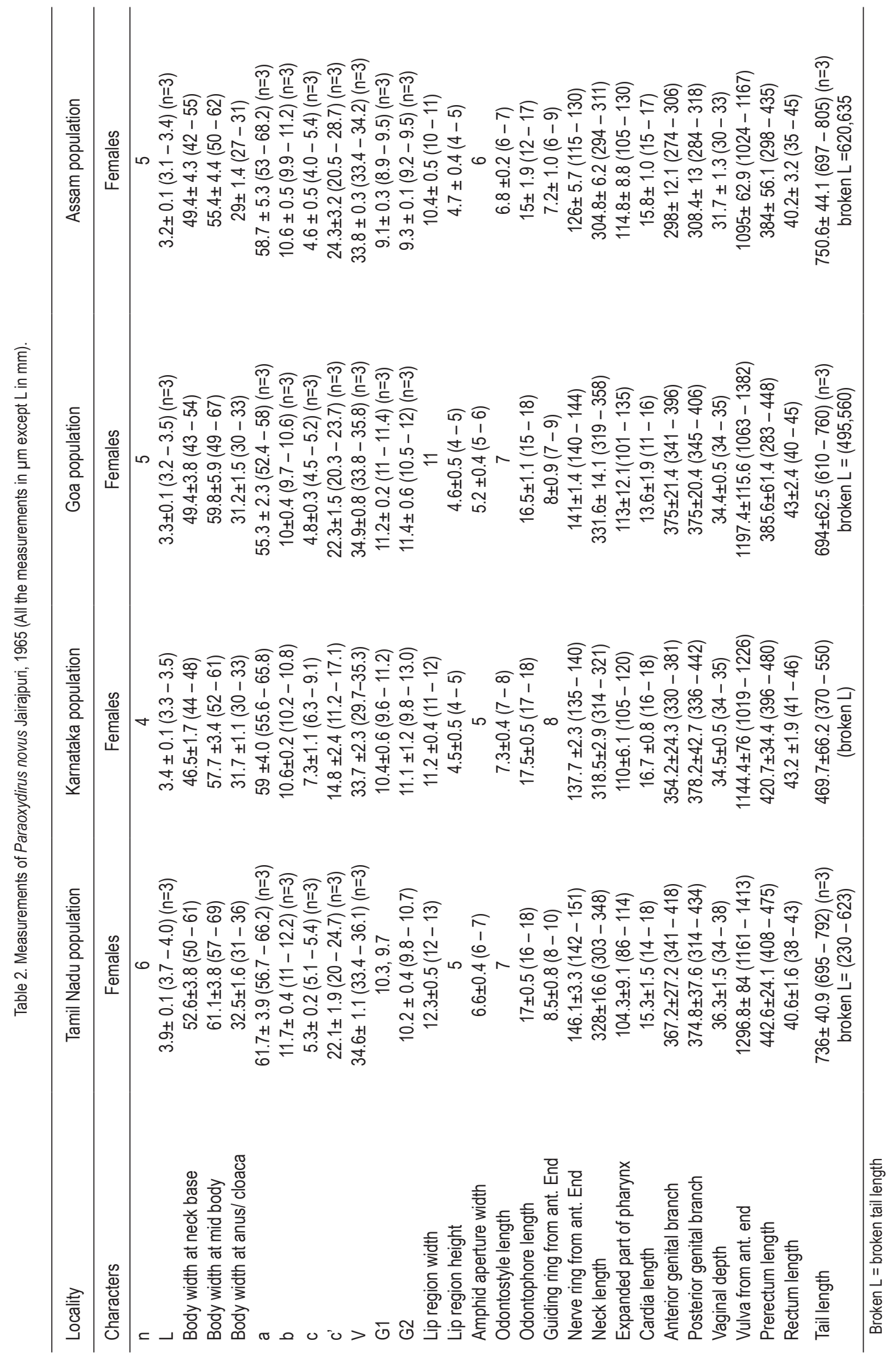


$125-197 \mu \mathrm{m}$ and posterior $130-205 \mu \mathrm{m}$ long, consisting of a long slender part with prismatic cells and a slightly wider pars dilatata with wide lumen. Sphincter present at oviduct-uterus junction. Uterus simple tube, anterior $131-226 \mu \mathrm{m}$ or $2.6-3.6$ times and posterior $142-231 \mu \mathrm{m}$ or $2.7-3.9$ times the corresponding body diameter long. Sperms not observed in genital tract. Vagina extending inwards about one-half to two-thirds $(51-69 \%$ ) of the corresponding body diameter; pars proximalis vaginae longer than wide, $17-25 \times 5-9 \mu \mathrm{m}$, with somewhat sigmoid walls, surrounded by circular muscles; pars refringens vaginae with two adjacent trapezoid-shaped pieces, $5-9 \times 5-10 \mu \mathrm{m}$, their combined width $14-22 \mu \mathrm{m}$; pars distalis vaginae $4-7 \mu \mathrm{m}$ with rounded walls. Vulva transverse. Prerectum $9.5-16$ and rectum $1.2-1.5$ times anal body diameter long. Tail long filiform, $20-28.7(n=9)$ times anal body diameter long. Caudal pores two; dorsal and lateral in position.

Male: Not found.

Habitats and localities: Soil samples collected from around the roots of: i) unidentified grasses from Mudumalai National Park, Nilgiri Hills, Nilgiri district, Tamil Nadu, India; coordinates $11^{\circ} 29^{\prime} 52.4940^{\prime \prime} N 76^{\circ} 37^{\prime} 47.0028^{\prime \prime}$ E on November 20, 2016; ii) unidentified grasses in paddy field from Canacona, South Goa, India; coordinates $14^{\circ} 59^{\prime} 35.21^{\prime \prime} \mathrm{N} 74^{\circ} 2^{\prime} 51.5^{\prime \prime}$ E on April 18, 2016; iii) unidentified plant roots from village Verna, South Goa, India; coordinates $15^{\circ} 21^{\prime} 52.01^{\prime \prime} \mathrm{N} 73^{\circ} 56^{\prime} 21.51^{\prime \prime}$ E on April 22, 2016; iv) unidentified shrub's from village Gajanur, Shimoga district, Karnataka, India; coordinates $13^{\circ} 50^{\prime 2} 20.4^{\prime \prime} \mathrm{N} 75^{\circ} 31^{\prime} 7.2^{\prime \prime}$ E on October 25, 2018; v) paddy field from district Tinsukia, Assam, India; coor-

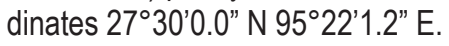

Remarks: $P$. novus is characterized by having $3.1-4.0 \mathrm{~mm}$ long body; lip region continuous, $10-13 \mu \mathrm{m}$ wide; amphidial fovea stirrup-shaped; guiding ring very conspicuous; odontostyle robust, $7-8 \mu \mathrm{m}$ long, its aperture about one-half of its length; expanded part of pharynx about $28-41 \%$ of total neck length; female genital system amphidelphic; vulva transverse, pre equatorial; pars refringens vaginae present; tail long filiform and males absent. Jairajpuri (1965) described this species as Oxydirus novus from the Andaman Island of India. Jairajpuri and Ahmad (1978) transferred it to their newly proposed genus Paraoxydirus as $P$. novus. Ferris, Goseco and Ferris (1980) in their revision of Belondiroidea transferred it to Tarjanius which was later returned back to Paraoxydirus by Ferris, Goseco and Ferris (1981). The present populations from various localities of India conforms well with the original description of Jairajpuri (1965) but differs in having slightly larger odontostyle aperture (about one-half vs one-third of odontostyle length); shorter cardia (one-third vs one-half) of corresponding body diameter long; longer vagina (one-half to two-thirds vs onethird) of body diameter; comparatively shorter prerectum (9.4-16 vs 17 times of anal body diameter long); slightly longer tail $\left(c^{\prime}=\right.$ $20.3-28.7$ vs 20). This is the first report of the species from main land India as well as first ever report after the original description.

\section{Paraoxydirus indicus n. sp.}

(Figs. $5 \& 6$ )

Measurements: See Table 3

Description: Adult: Large sized nematodes, slightly curved ventrad. Body cylindroid, tapering towards both extremities but more so towards the posterior end as tail is long filiform. Body cuticle with fine transverse striations, about $2 \mu \mathrm{m}$ thick along the body length, similar in both sexes except tail, $4-5 \mu \mathrm{m}$ and $3.0 \mu \mathrm{m}$ on tail in female and male respectively. Lateral chords with indistinct glandular bodies, 13 - $14 \mu \mathrm{m}$ wide, occupying about one-fourth $(23-24 \%)$ of mid-body diameter. Lip region low, slightly offset, gradually narrowing, $2.3-3.2$ times as wide as high and about one-fitth to one-third $(20-30 \%)$ of body diameter at neck base. Lips amalgamated, cephalic framework with poorly developed refractive elements; under SEM lip region continuous with the body contour, lips amalgamated; oral aperture triradiate, located in a ring-like elevation, surrounded by inner labial papillae that form parts of six small lobes distinctly protruding. Amphidial fovea cupshaped, their aperture occupying about $0.6-0.7$ times the lip region diameter, fusus slightly posterior to odontophore base level. Guiding ring single, very conspicuous, at $0.6-0.7$ times lip region diameter from anterior end. Odontostyle robust with wide lumen, $3.5-4.0$ times as long as wide, or about $0.5-0.6$ times the lip region diameter long, their aperture about one-half of its length. Odontophore simple, rod-like, $2.1-2.6$ times the odontostyle length. Nerve ring encircling the anterior slender part of pharynx at about $41-46 \%$ of neck length from anterior end. Anterior slender part of pharynx quite muscular, enlarging gradually; expanded part 3.9 5.4 times as long as wide, $2.2-2.6$ times as long as body diameter at pharynx base, occupying about $32-40 \%$ of total neck length, enclosed in a thick sheath of sinistrally spiral muscles. Pharyngeal gland nuclei and their orifices are located as follows: $\mathrm{DO}=67$; DN = 68; DO-DN = 0.3; S1N1 = 76; S1N2 = 77; S2N = $91(\mathrm{n}=1)$ as per Loof and Coomans (1970); $D=67 ; A S 1=28 ; A S 2=29 ; \mathrm{K}=97$; PSN $=70$ as Andrássy (1998). First pair of subventral gland nuclei almost at the same level. Cardia oblong, $1.6-2.3$ times as long as wide, occupying about two-fifths to one-half ( $42-53 \%$ ) of the corresponding body diameter. Well developed coelomocytes present, $32-110 \mu \mathrm{m}$ behind pharyngeal base, ovoid, measuring $20 \mathrm{x}$ $13-73 \times 20 \mu \mathrm{m}$; in addition, 5 - 18 smaller ones behind pharynx base to vulva and 5 - 8 in post-vulval region. Body pores indistinct. Female: Genital system didelphic-amphidelphic, posterior branch slightly longer than anterior genital branch, anterior 10.5, 9.3\% (n $=2)$ and posterior $12.7,11.3 \%(n=2)$ of total body length. Ovaries reflexed, not reaching oviduct-uterus junction, anterior $104-115$ $\mu \mathrm{m}$, and posterior $108-128 \mu \mathrm{m}$ long, with squamous shaped oocytes arranged in a single row except near tip. Oviduct joining ovary subterminally, anterior $158-212 \mu \mathrm{m}$ and posterior $185-$ $260 \mu \mathrm{m}$ long, consisting of a long slender part with prismatic cells and a slightly wider pars dilatata with distinct lumen. Sphincter present at oviduct-uterus junction. Uterus a simple tube filled with sperms, anterior $214-260 \mu \mathrm{m}$ or $3.7-4.0$ times and posterior 


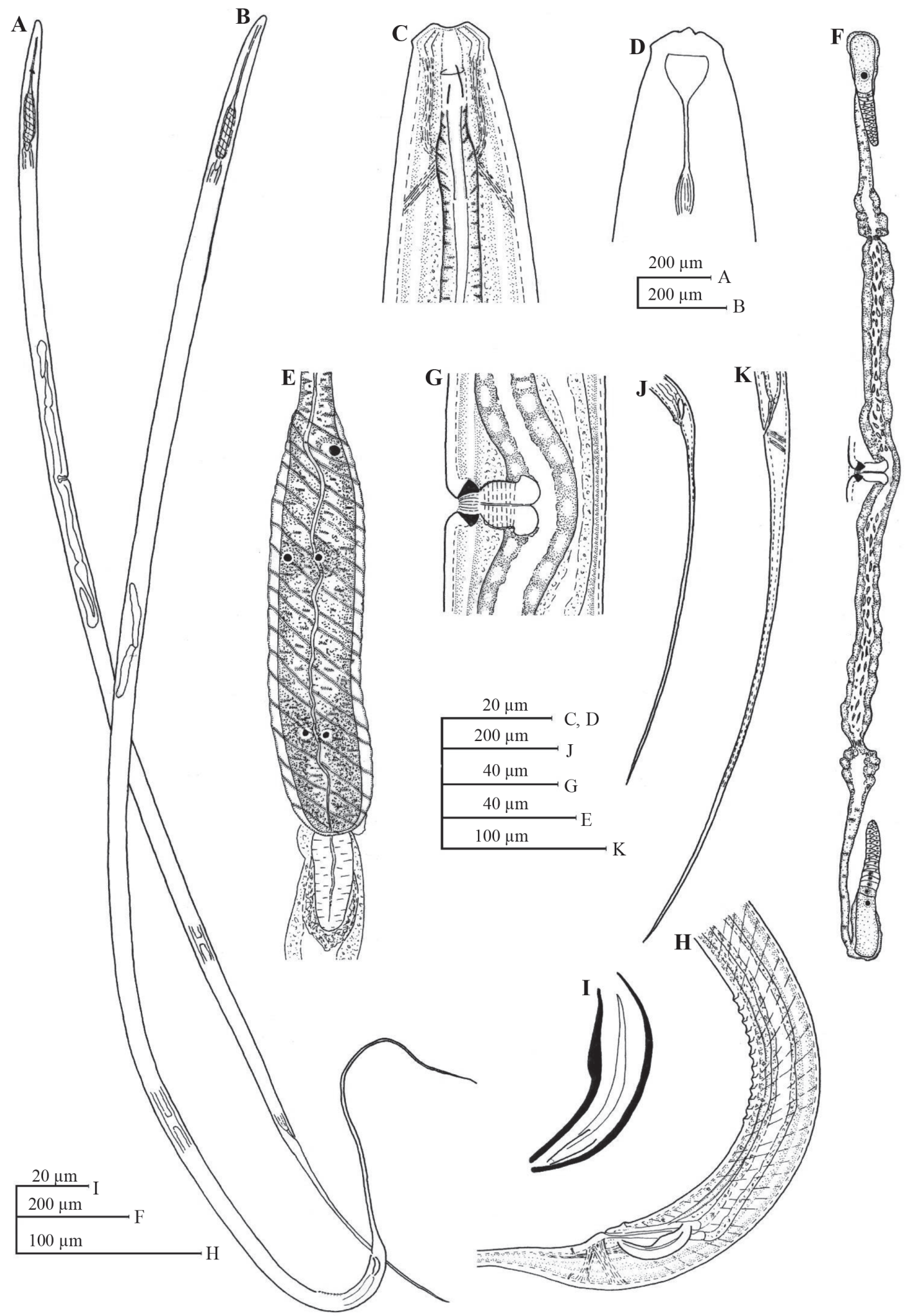

Fig. 5. Paraoxydirus indicus n. sp. (A) Entire female; (B) entire male; (C) anterior region; (D) anterior end showing amphid; (E) expanded part of pharynx; (F) female genital system; (G) vulval region; (H) male posterior region; (I) spicule; (J) male posterior region; (K) female posterior region. 

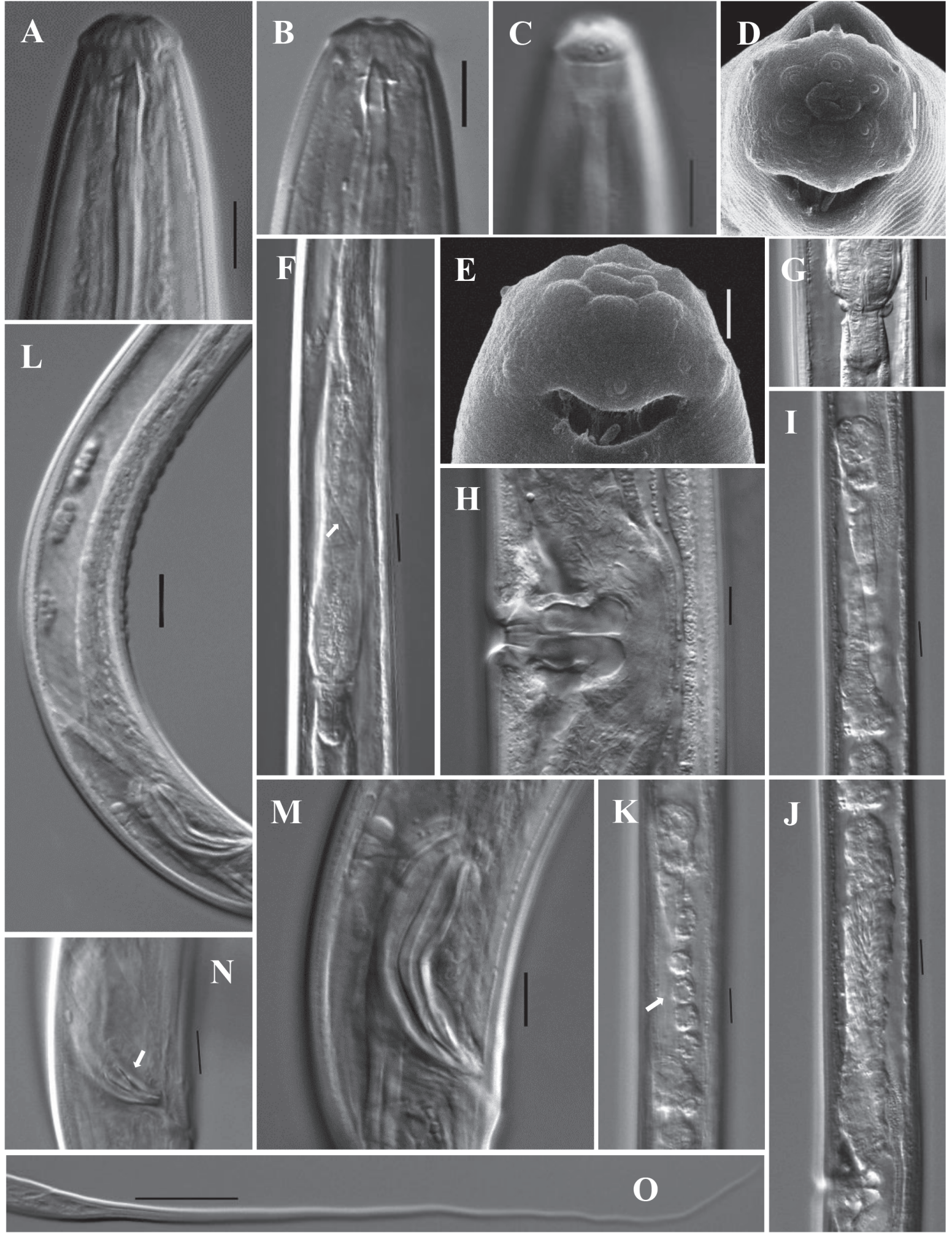

Fig. 6. Paraoxydirus indicus n. sp. (A, B) Anterior region; (C) anterior region showing amphid; (D) lip region in frontal view (female, SEM); (E) lateral view showing amphid (SEM); (F) pharyngeal expansion and spiral muscle sheath; (G) cardia; (H) vulval region; (I, J) female genital branch; (K) coelomocyte cells; (L) ventromedian supplements series; (M) spicule; (N) lateral guiding piece; (O) female tail. (Scale bars: A - C, G - H, M, N = $10 \mu \mathrm{m} ; \mathrm{D}, \mathrm{E}(\mathrm{SEM})=2 \mu \mathrm{m} ; \mathrm{F}, \mathrm{I-L}=20 \mu \mathrm{m} ; \mathrm{O}=100 \mu \mathrm{m}$ ). 
Table 3. Measurements of Paraoxydirus indicus $\mathrm{n}$. sp. (All the measurements in $\mu \mathrm{m}$ except $\mathrm{L}$ in $\mathrm{mm}$ ).

\begin{tabular}{|c|c|c|c|c|}
\hline \multirow{2}{*}{$\frac{\text { Locality }}{\text { Characters }}$} & \multicolumn{3}{|c|}{ Type population } & \multirow{2}{*}{$\frac{\text { Kerala population }}{\text { Female }}$} \\
\hline & $\begin{array}{l}\text { Holotype } \\
\text { female }\end{array}$ & Paratype females & Paratype males & \\
\hline$n$ & & 3 & 9 & 1 \\
\hline $\mathrm{L}$ & 4.0 & $4.0 \pm 0.4(3.6-4.6)$ & $3.8 \pm 0.1(3.7-4.0)(n=4)$ & 4.8 \\
\hline Body width at neck base & 48 & $50 \pm 2.2(48-53)$ & $47 \pm 2.4(44-51)$ & 60 \\
\hline Body width at mid body & 56 & $58 \pm 2.4(55-61)$ & $49.1 \pm 3.7(44-55)$ & 67 \\
\hline Body width at anus/ cloaca & 30 & $31 \pm 1.4(30-33)$ & $33.8 \pm 1.8(31-36)$ & 32 \\
\hline a & 72.8 & $70.4 \pm 4.5(66.1-76.6)$ & $78.7 \pm 4.2(72.8-82.2)(n=4)$ & 71.5 \\
\hline b & 12.2 & $11.2 \pm 0.7(10.4-12.2)$ & $11.5 \pm 0.6(11-12.5)(n=4)$ & 13.2 \\
\hline c & 5.4 & $6.3 \pm 0.4(5.85-6.6)$ & $5.4 \pm 0.2(5.2-5.7)(n=4)$ & 5.4 \\
\hline$c^{\prime}$ & 24.9 & $20.7 \pm 0.5(20-21.3)$ & $21.2 \pm 1.5(19.4-23.3)(n=4)$ & 27.9 \\
\hline V & 32.1 & $32.8 \pm 1.1(31.2-33.6)$ & - & 30.6 \\
\hline G1 & 10.5 & $10.1 \pm 0.4(9.7-10.7)$ & - & 9.3 \\
\hline G2 & 12.7 & $12.1 \pm 1.4(11-14)$ & - & 11.3 \\
\hline Lip region width & 13 & $13.6 \pm 0.5(13-14)$ & $12.8 \pm 0.6(12-14)$ & 12 \\
\hline Lip region height & 5 & $5 \pm 0.8(4-6)$ & $5.4 \pm 0.5(5-6)$ & 5 \\
\hline Amphid aperture & 8 & $8.3 \pm 0.5(8-9)$ & $7.6 \pm 0.8(7-9)$ & \\
\hline Odontostyle length & 7 & $7.5 \pm 0.4(7-8)$ & $7.4 \pm 0.4(7-8)$ & 7 \\
\hline Odontophore length & 17 & $17.6 \pm 0.5(17-18)$ & $17.3 \pm 1.0(16-19)$ & 17 \\
\hline Guiding ring from ant. End & 9 & $9.3 \pm 0.5(9-10)$ & $8.3 \pm 0.5(8-9)$ & 8 \\
\hline Nerve ring from ant. End & 153 & $149.3 \pm 6.0(141-155)$ & $146.5 \pm 2.1(142-149)$ & 153 \\
\hline Neck length & 334 & $361.6 \pm 14.3(347-381)$ & $344.7 \pm 15.4(314-366)$ & 362 \\
\hline Expanded part of pharynx & 107 & $122.6 \pm 6.6(114-130)$ & $114.3 \pm 10.3(102-129)$ & 146 \\
\hline Cardia length & 25 & $24 \pm 2.2(21-26)$ & $22 \pm 2.4(17-25)$ & 25 \\
\hline Anterior genital branch & 429 & $415 \pm 27.7(388-453)$ & - & 445 \\
\hline Posterior genital branch & 519 & $503 \pm 114.2(404-663)$ & - & 542 \\
\hline Vaginal depth & 34 & $31.6 \pm 1.2(30-33)$ & - & 35 \\
\hline Vulva from ant. End & 1310 & $1339 \pm 100(1217-1463)$ & - & 1464 \\
\hline Prerectum length & 519 & $545.3 \pm 41.9(500-601)$ & $532.5 \pm 79.8(412-660)$ & 597 \\
\hline Rectum length & 41 & $41.6 \pm 0.5(41-42)$ & $46.7 \pm 2.8(44-52)$ & 41 \\
\hline Tail length & 748 & $\begin{array}{c}642 \pm \\
(\text { broken } \mathrm{L})\end{array}$ & $\begin{array}{c}704 \pm 26.9(671-746)(n=4) \\
\text { broken L }(565-680)\end{array}$ & 894 \\
\hline Spicule length & - & - & $49.5 \pm 2.2(45-53)$ & - \\
\hline Lateral guiding pieces & - & - & $13.7 \pm 1.5(12-16)$ & - \\
\hline Ventromedian supplements & - & - & $12-15$ & - \\
\hline
\end{tabular}


$225-314 \mu \mathrm{m}$ or $4.1-5.4$ times the corresponding body diameter long. Vagina extending inwards, about one-half to three-fifths (52 $-60 \%$ ) of the corresponding body diameter; pars proximalis vaginae longer than wide, $21-25 \times 7-8 \mu \mathrm{m}$, with somewhat sigmoid walls and surrounded by circular musculature; pars refringens vaginae with two triangular pieces separated by an intermediate space, measuring $5-8 \times 4-8 \mu \mathrm{m}$, their combined width $14-$ $18 \mu \mathrm{m}$; pars distalis vaginae $5-6 \mu \mathrm{m}$ long with rounded walls. Vulva longitudinal. Prerectum $16.7-19.7$ and rectum $1.3-1.4$ times anal body diameter long. Tail long filiform, 27.9, $24.9(n=2)$ times anal body diameter long (tail terminus fragile, mostly broken off). Two pair of caudal pores present; subventral and subdorsal in position.

Male: Similar to female in general morphology, except for posterior region of the body being more ventrally curved. Genital system diorchic, with opposed outstretched testes. In addition to the adcloacal pair, located at $10-12 \mu \mathrm{m}$ from cloacal aperture, a series of $12-15$ irregularly spaced ventromedian supplements, $6-7$ $\mu \mathrm{m}$ apart, beginning at $84-101 \mu \mathrm{m}$ from the adcloacal pair; nine pairs of subventral precloacal papillae present. Copulatory muscles conspicuous, beginning from the level of middle of spicule to beyond the range of supplements series. Spicules typically dorylaimoid, robust, ventrally curved, total length along the arc, $1.0-1.3$ times as long as chord, $3-5$ times the maximum width and $1.3-1.7$ times the body diameter at cloacal aperture. Curvature about $125^{\circ}$. Dorsal contour regularly convex, ventral contour bearing prominent hump, located at $33-43 \%$ of spicules total length from its anterior end; head $2-5 \mu \mathrm{m}$ long, occupying about $4.0-9.4 \%$ of spicules length; median piece $16-24$ times as long as wide, occupying about $12-27 \%$ of spicules maximum width; posterior end $3-5 \mu \mathrm{m}$ wide. Lateral guiding pieces simple, $4-6$ times as long as wide or about one-fourth to one-third of spicules length. Prerectum $11.7-20.6$ and rectum about $1.2-1.7$ times cloacal body diameter long. Tail long filiform, about $19.4-23.3$ $(n=4)$ times cloacal body diameter long. Caudal pores four; two lateral, one dorsal and one ventral.

Type habitat and locality: From soil around the roots of unidentified grass from Mudumalai National Park, Nilgiri Hills, Tamil Nadu, India; coordinates $11^{\circ} 29^{\prime} 52.4940^{\prime \prime}$ N 76 $37^{\circ} 47.0028^{\prime \prime}$ E; collected on November 20, 2016.

Other habitat and locality: From around roots of unidentified grasses from the Chungathara, Malapuram, Kerala, India; coordinates $11^{\circ} 20^{\prime} 1.1^{\prime \prime} \mathrm{N} 76^{\circ} 16^{\prime} 32.44^{\prime \prime} \mathrm{E}$; collected on November 16, 2016.

Type specimens: Holotype female on slide Paraoxydirus indicus sp. n. / 1; paratype females and males on slides Paraoxydirus indicus sp. n. / $2-14$; deposited with the nematode collection of the Department of Zoology, Aligarh Muslim University, India.

Etymology: The new species is named after its type locality, India. Diagnosis and relationships: Paraoxydirus indicus $\mathrm{n}$. $\mathrm{sp}$. is characterized by having $4.0-4.8 \mathrm{~mm}$ long body; poorly offset lip region with amalgamated lips, 12-14 $\mu \mathrm{m}$ wide; amphidial fovea cup-shaped; guiding ring conspicuous; odontostyle $7-8 \mu \mathrm{m}$ long, robust; expanded part of pharynx about $32-40 \%$ of total neck length; female genital system amphidelphic; vulva longitudinal, pre-equatorial; tail long filiform, 27.9, 24.9 times anal body diameter in females and $19.4-23.3$ times cloacal body diameter in males; spicules $45-53 \mu \mathrm{m}$ long, robust and $12-14$ irregularly spaced ventromedian supplements. In the presence of a poorly offset lip region, robust odontostyle, distinct guiding ring and fusiform expanded part of pharynx, the new species come close to $P$. novus Jairajuri, 1965; P. magnus Timm, 1964 and $P$. pelinus Goseco, Ferris and Ferris, 1980 but differs from the former mainly in having slightly angular lip region (vs rounded); longitudinal vulva (vs transverse); in shape of pars refringens vaginae (two triangular pieces separated by an intermediate space vs two trapezoid pieces without intermediate space); in the presence of coelomocytes (vs not reported) and males present (vs male absent). From $P$. magnus Timm, 1964, it differs, in having relatively shorter (4.0 4.8 vs $4.9-5.7 \mathrm{~mm})$ and robust body $(\mathrm{a}=71-82$ vs $85-117)$; cephalic and labial papillae not interfering the labial contour (vs distinctly protruding); amphids cup-shaped (vs stirrup-shaped); differently shaped odontostyle (vs. odontostyle almost beak-shaped with anterior half of ventral arm distinctly bent dorsally); larger cardia (21 - 26 vs $8 \mu \mathrm{m}$ ); longitudinal vulva (vs transverse); longer prerectum ( $16-20$ vs 7 times anal body diameter long); longer tail ( $c=5.4$ vs $12.1-14.7 c^{\prime}=25-28$ vs 8 ); relatively shorter spicule ( $45-53$ vs $54-57 \mu \mathrm{m}$ ); ventral arm of spicules bearing distinct hump (vs smoothly arcuate) and coelomocytes present (vs not reported). From P. pelinus Ferris, Goseco and Ferris, 1980, it differs, in having smaller (4.0 -4.8 vs $5.2-5.4 \mathrm{~mm}$ ) and robust body $(a=71.4-73$ vs $102-140)$; wider lip region (13-14 vs 9 $\mu \mathrm{m})$; distinct guiding ring (vs guiding ring obscure); longer odontophore (17 - 18 vs $10 \mu \mathrm{m})$; longer pharynx ( $b=12.2-13.2$ vs $16.7-20.2)$; expanded part of pharynx slightly longer (32 - $40 \mathrm{vs}$ $30 \%$ ); longitudinal vulva (vs transverse); longer prerectum (500 601 vs $112-256 \mu \mathrm{m}$ ); longer tail ( $c=5.4$ vs $9-11 ; c^{\prime}=25-28$ vs 20); proximal part of spicule simple (vs proximal end appearing notched) and coelomocytes present (vs not reported).

\section{Paraoxydirus vulvalpapillatus $\mathrm{n} . \mathbf{s p}$.}

(Figs. 7, 8 \& 9)

Measurements: See Table 4

Description: Adult: Large sized nematodes, slightly curved ventrad, cylindroid, tapering towards both extremities but more so towards the posterior end as tail is long filiform. Cuticle with fine transverse striations, about $1-2 \mu \mathrm{m}$ thick at anterior region, $2-4$ $\mu \mathrm{m}$ at mid-body and $3-5 \mu \mathrm{m}$ on tail, similar in both sexes. Lateral chords with indistinct glandular bodies, $12-19 \mu \mathrm{m}$ wide, occupying about one-fourth to one-third (23-30\%) of mid-body diameter. Body pores indistinct. Lip regions almost continuous, gradually narrowing, $2.0-3.3$ times as wide as high and about one-fifth to two-seventh $(21-27 \%)$ of body diameter at neck base. Lips poorly angular, amalgamated; cephalic framework with poorly developed refractive elements; under SEM, lip region continuous 

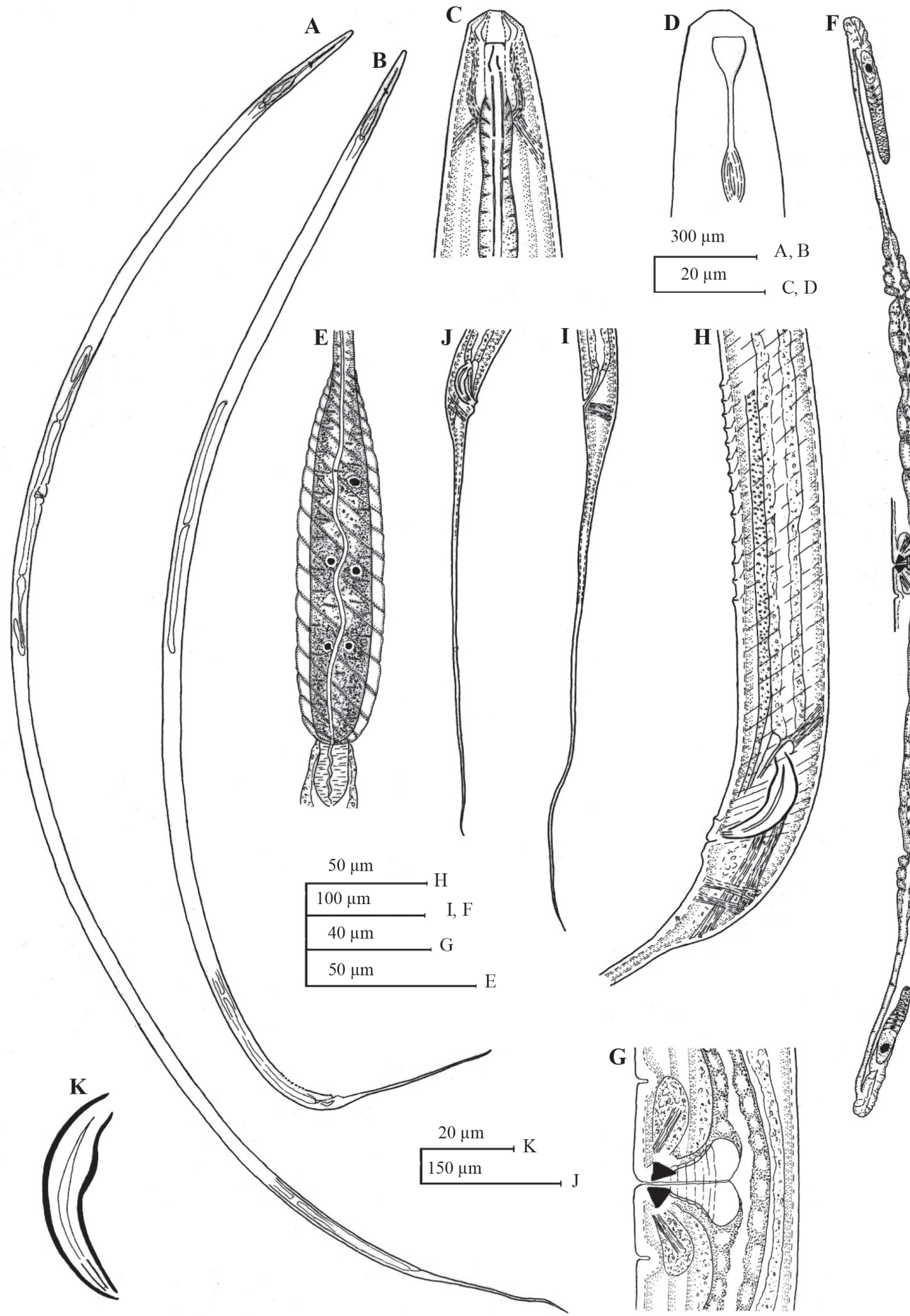

Fig. 7. Paraoxydirus vulvalpapillatus n. sp. (A) Entire female; (B) entire male; (C) anterior region; (D) anterior end showing amphid; (E) expanded part of pharynx; $(F)$ female genital system; $(G)$ vulval region; $(H)$ male posterior region; (I) female posterior region; (J) male posterior region; (K) spicule. 


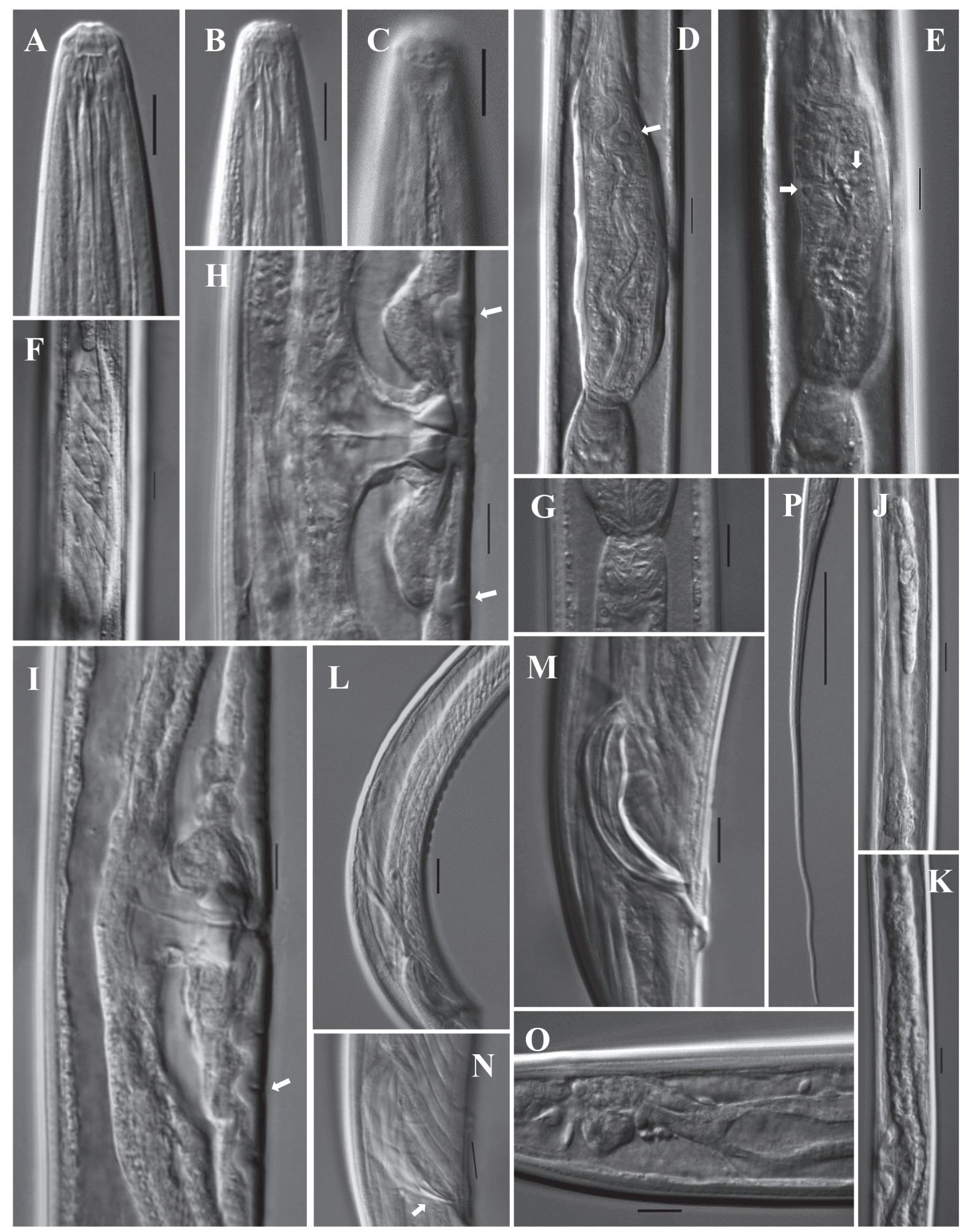

Fig. 8. Paroxydirus vulvalpapillatus n. sp. (A, B) Anterior region; (C) anterior end showing amphid; (D) expanded part of pharynx, DN; (E) S1N1, S1N2; $(F)$ spiral muscular sheath; $(\mathrm{G})$ cardia; $(\mathrm{H})$ vulval region, vulval papillae and pars refringens; (I) vulval papillae; $(\mathrm{J}, \mathrm{K})$ female genital branch; $(\mathrm{L})$ ventromedian supplements series; (M) spicule; (N) lateral guiding piece; (O) rectum; (P) female tail. (Scale bars: A - I, M - O =10 $\mu \mathrm{m} ; \mathrm{J}$ - L= $20 \mu \mathrm{m} ; \mathrm{P}=100 \mu \mathrm{m}$ ). 


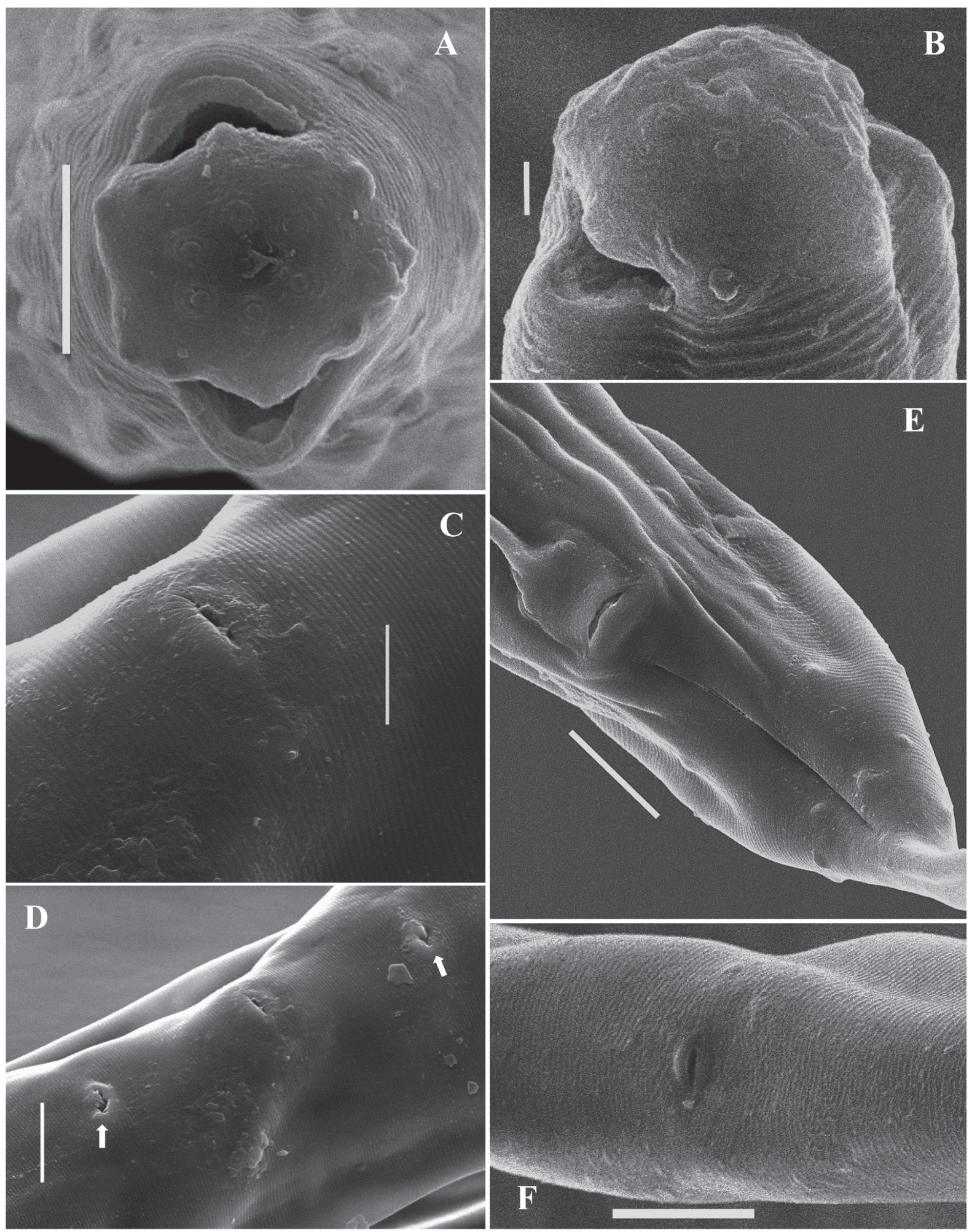

Fig. 9. Paraoxydirus vulvalpapillatus n. sp. (SEM). (A) Lip region in face view; (B) lip region in ventral view; (C) vulva in ventral view; (D) vulval papillae in ventral view; (E) male posterior ventral view, showing adclocal pair, caudal pores and cloacal opening; $(F)$ female anal opening in ventral view.

(Scale bars: $A, C=5 \mu \mathrm{m} ; B=1 \mu \mathrm{m} ; \mathrm{D}-\mathrm{F}=10 \mu \mathrm{m}$ ). 
Table 4. Measurements of Paraoxydirus vulvalpapillatus $\mathrm{n}$. sp. (All the measurements in $\mu \mathrm{m}$ except $\mathrm{L}$ in $\mathrm{mm}$ ).

\begin{tabular}{|c|c|c|c|c|}
\hline \multirow{2}{*}{$\begin{array}{l}\text { Locality } \\
\text { Characters }\end{array}$} & \multicolumn{3}{|c|}{ Type population } & \multirow{2}{*}{$\begin{array}{c}\begin{array}{c}\text { Karnataka } \\
\text { population } \\
\text { Female }\end{array}\end{array}$} \\
\hline & Holotype female & Paratype females & Paratype males & \\
\hline$n$ & 1 & 5 & 8 & 1 \\
\hline L & 4.8 & $4.6 \pm 0.3(4.3-4.9)$ & $4.4 \pm 0.5(3.8-5.0)(n=3)$ & 4.6 \\
\hline Body width at neck base & 40 & $42 \pm 1.3(41-44)$ & $42.1 \pm 2.4(38-45)$ & 47 \\
\hline Body width at mid body & 53 & $51.6 \pm 2.6(47-55)$ & $48.6 \pm 4.7(41-56)$ & 65 \\
\hline Body width at anus/ cloaca & 31 & $28.6 \pm 2.4(25-32)$ & $36 \pm 2.2(32-39)$ & 32 \\
\hline$a$ & 92 & $88.9 \pm 4.9(83.2-95.2)$ & $84.4 \pm 10.7(69.3-92.7)(n=3)$ & 71.6 \\
\hline b & 14.3 & $14.1 \pm 0.6(13-15)$ & $14.1 \pm 0.8(13-15)(n=3)$ & 13.2 \\
\hline C & 15 & $13.9 \pm 0.3(13.5-14.3)$ & $14.2 \pm 5.0(8.1-20.3)(n=3)$ & 14.9 \\
\hline$c^{\prime}$ & 10.5 & $11.2 \pm 1.2(9.7-12.6)$ & $9.8 \pm 3.6(6.8-14.8)(n=3)$ & 9.8 \\
\hline V & 36.3 & $37.8 \pm 1.6(35.6-39.5)$ & - & 41.6 \\
\hline G1 & 10.2 & $9.2 \pm 1.9(6.6-13.3)$ & - & 6.9 \\
\hline G2 & 10.5 & $11.2 \pm 0.7(10.2-11.7)$ & - & 7.6 \\
\hline Lip region width & 10 & $10.6 \pm 0.5(10-11)$ & $10.3 \pm 0.5(10-11)$ & 10 \\
\hline Lip region height & 4 & $4.2 \pm 0.7(3-5)$ & $4.5 \pm 0.5(4-5)$ & 3 \\
\hline Amphid aperture width & 5 & $5.0 \pm 0.6(4-6)$ & $6.3 \pm 0.7(5-7)$ & 5 \\
\hline Odontostyle length & 5 & $5.2 \pm 0.4(5-6)$ & $4.8 \pm 0.3(4-5)$ & 5 \\
\hline Odontophore length & 11 & $11.5 \pm 0.7(11-13)$ & $12 \pm 0.7(11-13)$ & 11 \\
\hline Guiding ring from ant. End & 5 & $5.2 \pm 0.4(5-6)$ & $5.3 \pm 0.5(5-6)$ & 4 \\
\hline Nerve ring from ant. End & 143 & $149.4 \pm 2.9(145-153)$ & $145.1 \pm 6.1(135-155)$ & 142 \\
\hline Neck length & 340 & $331.8 \pm 11.6(317-352)$ & $322.8 \pm 14.9(297-339)$ & 352 \\
\hline Expanded part of pharynx & 90 & $93 \pm 10.4(82-107)$ & $86.3 \pm 10.6(76-107)$ & 138 \\
\hline Cardia length & 13 & $15.6 \pm 2.2(12-19)$ & $13.1 \pm 2.5(11-19)$ & 15 \\
\hline Anterior genital branch & 499 & $469.2 \pm 102.6(288-575)$ & - & 320 \\
\hline Posterior genital branch & 512 & $514 \pm 33.2(492-580)$ & - & 356 \\
\hline Vaginal depth & 30 & $30.2 \pm 0.7(29-31)$ & - & 34 \\
\hline Vulva from ant. end & 1770 & $1703 \pm 115.8(1550-1896)$ & - & 1934 \\
\hline Prerectum length & 455 & $373.7 \pm 42.5(315-435)$ & $486.7 \pm 61(432-602)$ & 290 \\
\hline Rectum length & 37 & $36.6 \pm 2.7(32-40)$ & $46.7 \pm 2.6(42-50)$ & 43 \\
\hline Tail length & 325 & broken $L=310-365$ & $\begin{array}{c}341 \pm 97(247-475)(n=3) \text { (broken } \\
L=185-279)\end{array}$ & 312 \\
\hline Spicule length & - & - & $51 \pm 2.5(46-54)$ & - \\
\hline Lateral guiding pieces & - & - & $12.5 \pm 1.6(11-16)$ & - \\
\hline Ventromedian supplements & - & - & $11-14$ & - \\
\hline
\end{tabular}

Broken $L=$ (Broken tail length) 


\begin{tabular}{|c|c|c|c|c|c|c|c|c|c|c|c|c|}
\hline & & 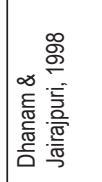 & & 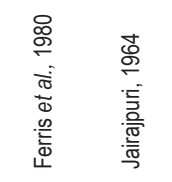 & & 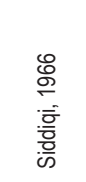 & 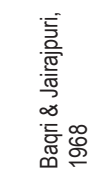 & & 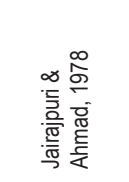 & & 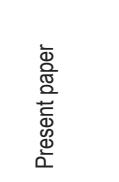 & 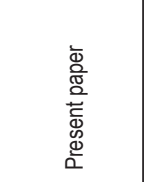 \\
\hline 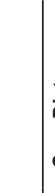 & 容 & 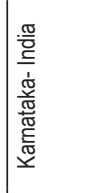 & & 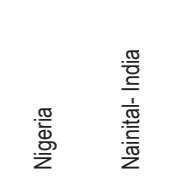 & & 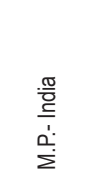 & 譥 & & 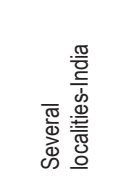 & & 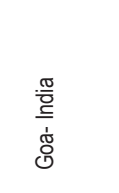 & 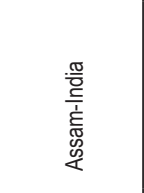 \\
\hline & 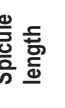 & & 䗜 & , 总 & is & g & & 商 & & 总 & 聴 & 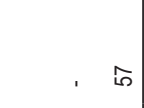 \\
\hline & 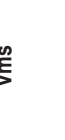 & & 吕 & $\stackrel{\infty}{\stackrel{\infty}{2} .}$ & 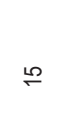 & 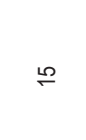 & & $\cong$ & & $\stackrel{P}{\stackrel{P}{=}}$ & , & $\therefore$ \\
\hline 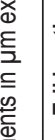 & E⿸\zh14 & 䌟 & 墨 & 怘䯧 & 兽 & & & & 䇾 & 善 & 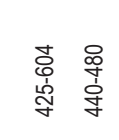 & $\begin{array}{l}\text { 䅭 } \\
\text { 嘉 }\end{array}$ \\
\hline . & : & 㩊 & 嵒 & 衰 & s. & & & & 愛 & & 总亳 & 号 \\
\hline & 定 & 志 & 莒 & $\underset{\substack{q \\
\stackrel{f}{\alpha}}}{ }$ & $\dot{m}$ & & . & . & 葶 & 总 & 窟总 & 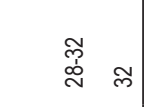 \\
\hline t & 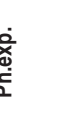 & 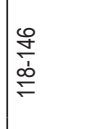 & 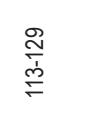 & 旁喜 & & & & & 宔 & & 䪪言 & 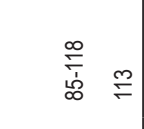 \\
\hline 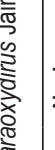 & 啚 & 孚 & 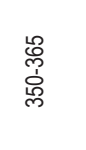 & 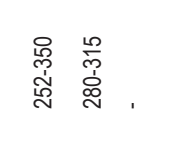 & & & & & 絗 & 骨 & 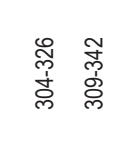 & 苨 \\
\hline & 参 & $\infty$ & $\infty$ & is , is & is & $\circ$ & in & & $\tilde{6}$ & $\hat{\sigma}$ & 品以 & \begin{tabular}{lll} 
& $\circ$ \\
\hdashline & $\circ$
\end{tabular} \\
\hline & $g$ & $\simeq$ & & & 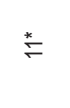 & & . & . & $\approx$ & & 产 & $\div$ \\
\hline & $>$ & 总 & & & & & \& & . & 虽 & & 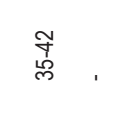 & 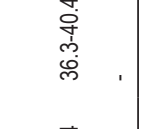 \\
\hline & . & ळ్ & $\stackrel{\circ}{\dot{8}}$ & 离 & $\cong$ & & & . & $\ddagger$ & 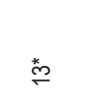 & 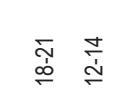 & 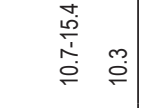 \\
\hline & 。 & $\overline{\bar{\alpha}}$ & $\stackrel{\circ}{\stackrel{2}{2}}$ & 扂品。 & $\stackrel{\Upsilon}{\stackrel{(}{=}}$ & \pm & 0 & 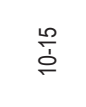 & $\stackrel{\bar{I}}{\equiv}$ & 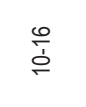 & $\stackrel{\infty}{2} \stackrel{\circ}{\ddot{\infty}}$ & $\overline{\bar{o}} \bar{\circ}$ \\
\hline & o & 䊦 & $\stackrel{\circ}{\ddagger}$ & 言尊愛 & ֻू & $\cong$ & $\cong$ & 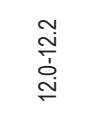 & 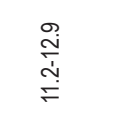 & 突 & 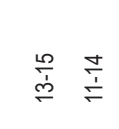 & $\stackrel{\text { pos }}{=} \stackrel{0}{=}$ \\
\hline & $\sigma$ & 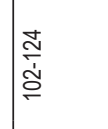 & 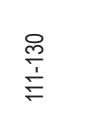 & 带兽品 & 怘 & $\infty$ & $\therefore$ & 置 & $\stackrel{\mathscr{B}}{\circledR}$ & 獣 & 累兽 & 等索哭 \\
\hline & 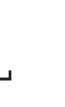 & 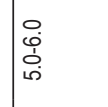 & 高 & 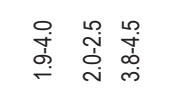 & 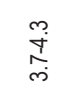 & ले & ळ & 芦 & $\underset{\substack{0 \\
0}}{\substack{0\\
}}$ & 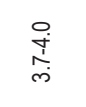 & 总兴 & 喜 \\
\hline & $=$ & 斿 & 点 & 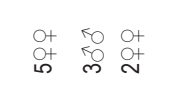 & 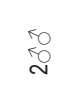 & 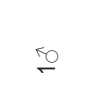 & $\stackrel{+}{+}$ & 赵 & 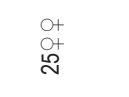 & $\begin{array}{ll}\circ \\
:\end{array}$ & 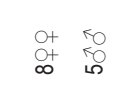 & 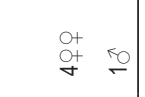 \\
\hline & & 商 & & 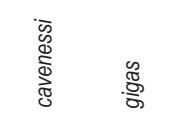 & & & & & & & & \\
\hline
\end{tabular}




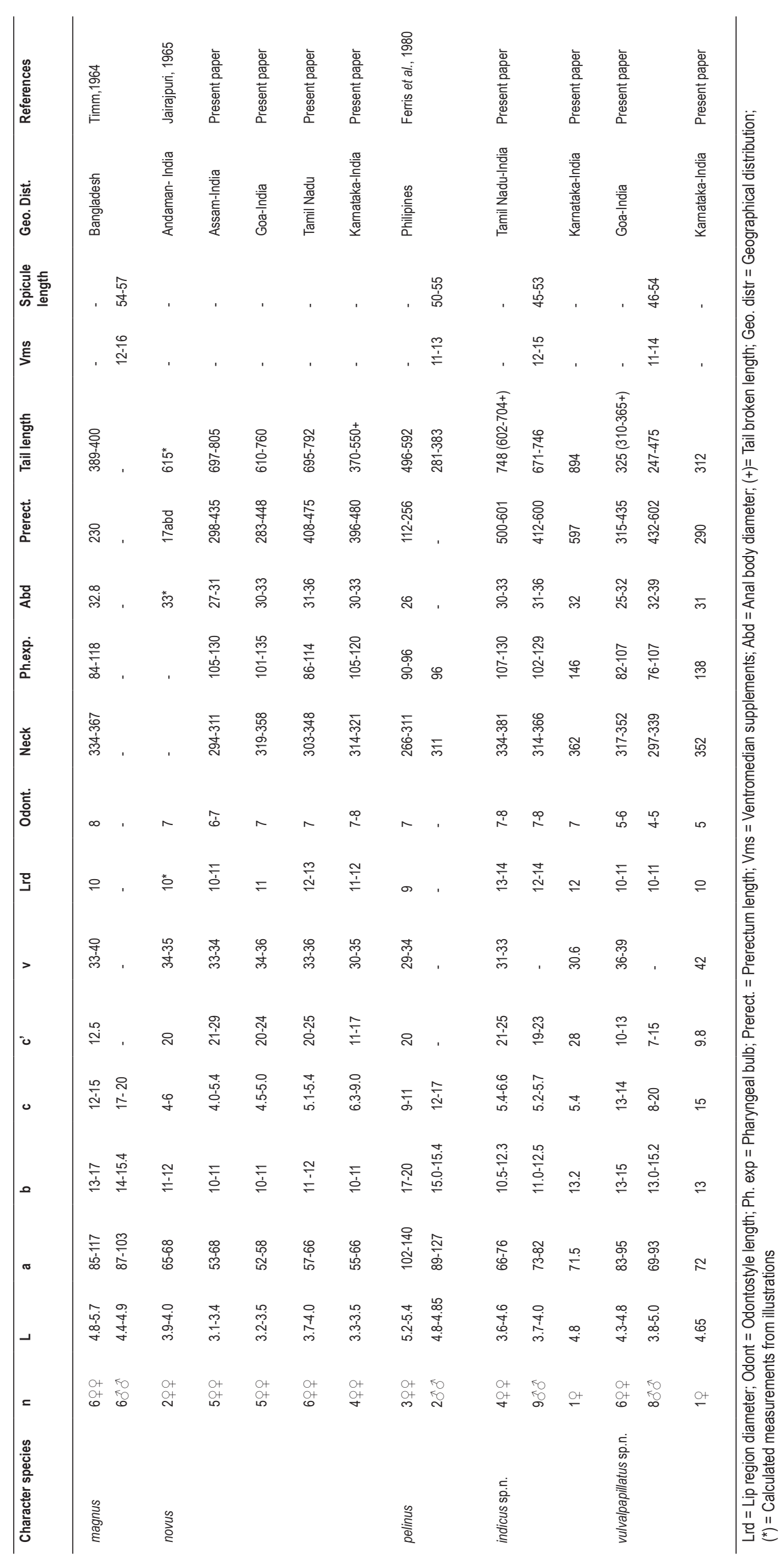


with amalgamated lips; cephalic papillae distinctly protruding, labial papillae low, weakly protruding; inner labial papillae button-like, and surrounded by an annulus. Amphidial fovea cup-shaped, their aperture occupying about $0.4-0.5$ times the lip region diameter, fusus slightly posterior to the odontophore base level. Guiding ring single, at $0.4-0.5$ times lip region diameter from the anterior end. Odontostyle slender, irregular in shape, its ventral arm bent toward dorsal arm, $5-6$ times as long as wide, about $0.4-0.6$ times the lip region diameter long, its aperture about one-fourth to one-third of its length. Odontophore simple, rod-like, 2.0 - 2.4 times the odontostyle length. Nerve ring encircling the anterior slender part of the pharynx at $40-47 \%$ of neck length from anterior end. Anterior slender part of pharynx quite muscular, expanding gradually; expanded part 3.0 - 4.6 times as long as wide, $2.1-2.7$ times as long as body diameter at neck base, occupying about $28-36 \%$ of total neck length, enclosed in a thick sheath of sinistrally spiral muscles. Pharyngeal gland nuclei and their orifices are located as follows: $\mathrm{DO}=69-77 ; \mathrm{DN}=70-77 ; \mathrm{DO}-\mathrm{DN}=0.3-0.6$; S1N1 = 81 - 84; S1N2 = $82-86(n=3) ; \mathrm{S} 2 \mathrm{~N}=92(\mathrm{n}=1)$; as per Loof and Coomans (1970); $\mathrm{D}=73-77 ; \mathrm{AS} 1=29-30 ; \mathrm{AS} 2=31-32 ; \mathrm{K}$ = 92 - 96; PSN = 65, 67 as per Andrássy (1998). Cardia oblong, 1.1 - 1.6 times as long as wide, occupying about two-seventh to two-fifths ( $28-43 \%$ ) of corresponding body diameter.

Female: Genital system didelphic-amphidelphic, both branches al- most equally developed, anterior $6.8-10.2 \%(n=2)$ and posterior $7.6-10.5 \%(n=2)$ of body length. Ovaries reflexed, not reaching oviduct-uterus junction, anterior 94 - $156 \mu \mathrm{m}$, and posterior 94 $160 \mu \mathrm{m}$ long, with squamous-shaped oocytes arranged in a single rows except near tip. Oviduct joining ovary subterminally, anterior 125 - $314 \mu \mathrm{m}$ and posterior 136 - $300 \mu \mathrm{m}$ long, consisting of long slender part with prismatic cells and a slightly wider pars dilatata with wide lumen. Sphincter present at oviduct-uterus junction. Uterus a simple tube filled with sperms, anterior $190-260 \mu \mathrm{m}$ or $3-5$ times and posterior $187-277 \mu \mathrm{m}$ or $2.9-5.3$ times the corresponding body diameter long. Vagina extending inwards, about one-half to three-fifths $(52-62 \%)$ of the corresponding body diameter; pars proximalis vaginae longer than wide, $16-21 \times 6$ $-9 \mu \mathrm{m}$, with somewhat sigmoid walls and surrounded by circular musculature; pars refringens vaginae with two asymmetrical triangular pieces, separated by a narrow intermediate space, $8-10 \times$ $6-7 \mu \mathrm{m}$, their combined width $12-19 \mu \mathrm{m}$; pars distalis vaginae $4-7 \mu \mathrm{m}$ with rounded walls. Vulva transverse slit, about $4 \mu \mathrm{m}$ wide with prominent lips. Vulval papillae conspicuous, 1 - 13 in numbers. Prerectum $9-15$ and rectum $1.0-1.6$ times anal body diameter long. Tail long, filiform, 9.8, 10.5 ( $n=2$ not broken) times anal body diameter long (tail terminus fragile, mostly broken off). Caudal pores three on each side; one dorsal, sub-ventral and lateral respectively.

Key to species of the genus Paraoxydirus

1. Odontostyle robust, with comparatively wide aperture .................................................

Odontostyle slender, with comparatively narrow aperture ......................................................

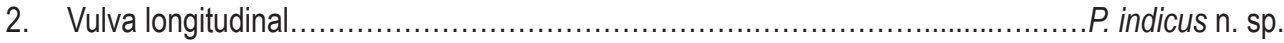

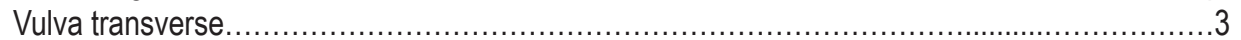

3. Body length $3.1-4.0 \mathrm{~mm}$; guiding ring very conspicuous, irregular in shape; $c=4.0-6.0$ in females. P. novus Jairajpuri, 1965

Body length $4.8-5.7 \mathrm{~mm}$; guiding ring simple, less conspicuous; $\mathrm{c}=9-15$ in females. 4

4. Odontostyle $9 \mu \mathrm{m}$ long, irregular in shape; amphids stirrup-shaped; expanded part of the pharynx $32-35 \%$ of total neck length; c' $=12.5$; spicules slightly arcuate, anterior part not notched. .....

.P. magnus Timm, 1964

Odontostyle $7 \mu \mathrm{m}$, regular in shape; amphids cup-shaped; expanded part of the pharynx $30 \%$ of total neck length; $c^{\prime}=20$; spicules strongly arcuate, its proximal part appearing notched.....

P. pelinus Ferris, Goseco \& Ferris, 1980

5. Body $5.0-6.0 \mathrm{~mm}$ long, slender $(a=102-124)$; amphids stirrup-shaped; vulva pore-like;...

P. abnormus Dhanam \& Jairajpuri, 1998

Body 1.9 - $4.8 \mathrm{~mm}$ long, comparatively robust ( $a=59$ - 95); amphids cup-shaped; vulva transverse.

6. Vulval papillae present

P. vulvalpapillatus n. sp. Vulval papillae absent......

7. Expanded part of pharynx about $28-35 \%$ of total neck length; spicules robust, $48-57 \mu \mathrm{m}$ long; ventromedian supplements $11-15$. P. gigas Jairajpuri, 1964 Expanded part of pharynx $36-42 \%$ of total neck length; spicules comparatively slender $36-37 \mu \mathrm{m}$ long; ventromedian supplements $7-8$....... P. cavenessi Ferris, Goseco \& Ferris, 1980 
Male: Similar to female in general morphology, except for posterior region of the body being more ventrally curved. Genital system diorchic, with opposed outstretched testes. In addition to the adcloacal pair, located at $7-9 \mu \mathrm{m}$ from cloacal aperture, a series $11-14$ irregularly spaced ventromedian supplements, 7 - $10 \mu \mathrm{m}$ apart, beginning at $62-101 \mu \mathrm{m}$ from the adcloacal pair. Copulatory muscles conspicuous, beginning from posterior end of spicule to beyond the range of supplements series. Spicule dorylaimoid, robust, slightly curved ventrad, total length along the arc $1.0-1.1$ times as long as chord, $4.6-6.0$ times the maximum width and 1.2 1.5 times body diameter at cloacal aperture. Curvature about $130^{\circ}$. Dorsal contour regularly convex, ventral contour bearing prominent hump, located at $35-41 \%$ of spicules total length from its anterior end; head $5-7 \mu \mathrm{m}$ long, occupying $9-13 \%$ of total length; median piece $22-49$ times as long as wide, and occupying $9-11 \%$ of spicules maximum width. Posterior end $3-5 \mu \mathrm{m}$ wide. Lateral guiding pieces simple, $5-8$ times as long as wide or about onefourth to one-third of spicules length. Prerectum $11.8-15.3$ and rectum $1.1-1.6$ times cloacal body diameter long. Tail long filiform, about $6.9-14.8(n=3)$ times cloacal body diameter long. Caudal pores four; one ventral, one dorsal and two lateral in position.

Type habitat and locality: From soil around roots of unidentified plant near the Cuncolim, South Goa, India; coordinates 15¹0'38.28" N 7359'38.11" E; collected on April 20, 2016.

Other locality: From soil around roots of unidentified plant near Thirthahalli, Shimoga, Karnataka; India; coordinates $13^{\circ} 41^{\prime 22.19^{\prime \prime}}$ N 75¹4'41.96" E; collected on October 25, 2018.

Type specimens: Holotype female on the slide Paraoxydirus vulvalpapillatus n. sp. /1; paratype females and males on slides Paraoxydirus vulvalpapillatus n. sp. $/ 2$ - 14; deposited with the nematode collection of the Department of Zoology, Aligarh Muslim University, India.

Etymology: The new species is named vulvalpapillatus because of the presence of vulval papillae.

Diagnosis and relationships: Paraoxydirus vulvalpapillatus $\mathrm{n}$. $\mathrm{sp}$. is characterized by having $4.6-4.8 \mathrm{~mm}$ long body; lip region almost continuous with body with amalgamated lips, $10-11 \mu \mathrm{m}$ wide; amphidial fovea cup-shaped, guiding ring single; odontostyle slender, $5-6 \mu \mathrm{m}$ long, asymmetrical; expanded part of pharynx about $28-36 \%$ of total neck length; female genital system amphidelphic; transverse vulva, pre-equatorial; vulval papillae conspicuous; tail long filiform similar in sexes; male with $46-54 \mu \mathrm{m}$ long dorylaimoid spicules and $11-14$ continuous ventromedian supplements. In the presence of slender odontostyle, transverse vulva, robust dorylaimoid spicules, and number of ventromedian supplements, the new species come close to $P$. gigas Jairajpuri, 1964, and P. cavenessi Ferris, Goseco and Ferris, 1980 but differs from the former in having ventral arm of odontostyle strongly bent toward dorsal arm (vs ventral arm slightly bent at tip); prominent vulval papillae (vs absent); shape of pars referinges vaginae (triangular vs trapezoid). From P. cavenessi Ferris, Goseco and Ferris, 1980 , it differs, in having irregular shaped odontostyle (vs regular in shape); longer cardia (12 - 19 vs $10 \mu \mathrm{m}$ ); vulval papillae present (vs absent); longer prerectum (10 - 15 vs $7-9$ times anal body diameter long); higher number of ventromedian supplements (11 - 14 vs 7 - 8); longer spicules (46 - 54 vs $36-37 \mu \mathrm{m})$. It also comes close to P. magnus Timm, 1964, but differs, in having relatively slender and shorter odontostyle ( 5 - 6 vs $9 \mu \mathrm{m}$ with wide lumen); amphidial fovea (cup-shaped vs stirrup-shaped); longer prerectum ( $9-15$ vs 7 times anal body diameter long); prominent vulval papillae (vs absent); slightly shorter spicules (46 - 54 vs 54 $-57 \mu \mathrm{m}$ or $1.2-1.5$ vs 2 times anal body diameter long); ventral arm of spicules bearing a distinct hump (vs without distinct hump or smoothly arcuate).

\section{Acknowledgments}

The authors are thankful to the Chairman, Department of Zoology for providing necessary laboratory facilities. The first author also thanks the University Grants Commission, Govt. of India for providing financial assistance under UGC-RGNF Fellowship.

\section{References}

ANDRÁSSY, I. (1998): Once more the oesophageal gland nuclei in the dorylaimid nematodes. Opusc Zool, 31: $165-170$

BAqRI, Q.H., JaIRAJPURI, M.S. (1968): Studies on Belondiroidea (Nematoda) from India. Nematologica, 14: 300 - 310. DOI: 10.1163/187529268X00516

CовB, N.A. (1918): Estimating the nema population of the soil. United States Department of Agriculture, Bureau of plant Industry, Agriculture Technical Circular, 1: 1- 48

Courtney, W.D., Polley, D., Miller, V.L. (1955): TAF, an improved fixative in nematode technique. Plant Dis, 39: 570 - 571

Dhanam, M. \& JaIRAJPURI, M.S. (1998): New belondirid nematodes: Two new genera, two new subgenera and seven new species from the Malnad Tracts of Karnataka, India. Int J Nematol, 8 (2): 193 213

Ferris, V.R., Goseco, C.G., Ferris, J.M. (1980): Revision of Oxydirus and Tarjanius n. gen. in Oxydiridae, Belondiroidea (Nematoda: Dorylaimida); and Oxydiroides in Prodorylaiminae, Dorylaimidae. Research Bulletin Purdue University, Agricultural Experiment Station, West Lafayette, Indiana, No. 956: 29 pp.

FerrIS, V.R., Goseco, C.G., FerRIS, J.M. (1981): Tarjania a junior synonym of Paraoxydirus and emended description of Paraoxydirus (Nematoda: Dorylaimida). Nematologica, 27: 350 - 351. DOI: $10.1163 / 187529281 \times 00593$

JAIRAJPURI, M.S., AHMAD, M. (1978): Some remarks on the genus Oxydirus Thorne, 1939 with proposal of Paraoxydirus n. gen. Indian J Nematol, 8: 146 - 148

JAIRAJPURI, M.S. (1964): Studies on Nygellidae $n$. fam. and Belondiridae Thorne, 1939 (Nematoda: Dorylaimoidea) with description of ten new species from India. Proc Helminthol Soc Wash, 31: 173 $-187$ 
JAIRAJPURI, M.S. (1965): Three new species of Dorylaimoidea (Nematoda) from India. Proc Helminthol Soc Wash, 32: 78 - 81 Loof, P.A.A., Coomans, A. (1970): On the development and location of the oesophageal gland nuclei in the Dorylaimina. Proc. IX Int. Nem. Symp. (Warsaw, 1967), 79 - 161. DOI: 10.1163/187529268X00345

Peña-Santiago, R., Abolafia, J. \& Alvarez-Ortega, S. (2014): New proposal for a detailed description of the dorylaim spicule (Nematoda: Dorylaimida). Nematology, 16: 1091 - 1095. DOI: 10.1163/15685411-00002834
SEINHORST, J.W. (1959): A rapid method for the transfer of nematodes from fixative to anhydrous glycerin. Nematologica, 4: 67 69. DOI: $10.1163 / 187529259 \times 00381$

SIDDIQI, M.R. (1966): Studies on species of Belondiroidea (Nematoda: Dorylaimida) from India. Proc Helminthol Soc Wash, 22: 139 $-149$

THORNE, G. (1939): A monograph of the nematodes of the superfamily Dorylaimoidea. Capita Zool, 8: 1 - 261

TIMM, R.W. (1964): Nematode of the superfamily Dorylaimoidea from East Pakistan. Proc Helminthol Soc Wash, 31: 144 - 153 